\title{
Ecophysiological differentiation between life stages in filmy ferns (Hymenophyllaceae)
}

Joel H. Nitta ${ }^{1,4}$, James E. Watkins, Jr. ${ }^{2}$, N. Michele Holbrook ${ }^{1}$, Tristan W. Wang ${ }^{1,3}$, and Charles C. Davis ${ }^{1}$

${ }^{1}$ Department of Organismic and Evolutionary Biology and Harvard University Herbaria, Harvard University, Cambridge, Massachusetts 02138 USA

${ }^{2}$ Department of Biology, Colgate University, 13 Oak Drive, Hamilton, New York 13346 USA

${ }^{3}$ Current affiliation: Section of Plant Pathology and Plant-Microbe Biology, Cornell University, Ithaca, New York 14853 USA

${ }^{4}$ Current affiliation: Department of Biological Sciences, Graduate School of Science, The University of Tokyo, 2-11-16 Yayoi, Bunkyo-ku, Tokyo 113-0032, Japan

Author for correspondence: Joel Nitta (joelnitta@gmail.com)

ORCID ID numbers

Joel H. Nitta: https://orcid.org/0000-0003-4719-7472

N. Michele Holbrook: https://orcid.org/0000-0003-3325-5395

Tristan W. Wang: https://orcid.org/0000-0001-6889-2453

Charles C. Davis: https://orcid.org/0000-0001-8747-1101

\section{Abstract}

Desiccation tolerance was a key trait that allowed plants to colonize land. However, little is known about the transition from desiccation tolerant non-vascular plants to desiccation sensitive vascular ones. Filmy ferns (Hymenophyllaceae) represent a useful system to investigate how water-stress strategies differ between non-vascular and vascular stages within a single organism because they have vascularized sporophytes and nonvascular 
gametophytes that are each capable of varying degrees of desiccation tolerance. To explore this, we surveyed sporophytes and gametophytes of 19 species (22 taxa including varieties) of filmy ferns on Moorea (French Polynesia) and used chlorophyll fluorescence to measure desiccation tolerance and light responses. We conducted phylogenetically informed analyses to identify differences in physiology between life stages and growth habits. Gametophytes had similar or less desiccation tolerance (ability to recover from 2 d desiccation at -86 MPa) and lower photosynthetic optima (maximum electron transport rate of photosystem II and light level at $95 \%$ of that rate) than sporophytes. Epiphytes were more tolerant of desiccation than terrestrial species in both life stages. Despite their lack of greater physiological tolerances, gametophytes of several species occurred over a wider elevational range than conspecific sporophytes. Our results demonstrate that filmy fern gametophytes and sporophytes differ in their physiology and niche requirements, and point to the importance of microhabitat in shaping the evolution of water-use strategies in vascular plants.

Keywords: chlorophyll fluorescence; desiccation tolerance; DNA barcoding; French Polynesia; gametophyte; Hymenophyllaceae 


\section{Introduction}

The movement of plants from water to land was one of the most important evolutionary events in the history of the earth, fundamentally altering the global carbon and water cycle and setting the stage for modern terrestrial ecosystems (Graham 1993; Kenrick and Crane 1997). The transition from aquatic to terrestrial growth was complex, requiring a suite of evolutionary adaptations to survive in deadly dry habitats bombarded with radiation (Waters 2003). Lacking mechanisms to regulate water loss, the earliest land plants were likely poikilohydric, i.e., they existed in a state of equilibrium with the humidity of the external environment (Raven 1999). Therefore, one particularly important early adaptation that enabled plants to survive on land was desiccation tolerance (DT), the ability to lose all metabolically active water, reach equilibrium with atmospheric humidity, and recover upon rewetting (Mishler and Churchill 1985).

Compared with the ubiquitous DT among the earliest land plants, the occurrence of DT varies across extant land plant lineages and life stages. Many bryophytes have retained vegetative DT in the gametophyte stage (Oliver et al. 2005, and references therein). In extant vascular plants (tracheophytes), DT occurs in certain non-vegetative stages (e.g., seeds and pollen), but has largely been lost in vegetative tissues [with some notable exceptions, the so-called 'resurrection plants'; Hartung et al. (1998); Kappen and Valladares (2007); Scott (2000)]. Instead, the majority of tracheophytes solely rely on avoiding desiccation with adaptations including a waxy cuticle, stomata, roots, and an extensive vascular system. Correlated with these differences in functional strategies to cope with water stress is a major difference in life cycle. Over time, plants shifted away from wholly gametophyte-dominated life cycle (as in extant bryophytes) to co-independence of the gametophyte and sporophyte (i.e., ferns and lycophytes) to complete loss of the independent gametophyte (i.e., spermatophytes). Little is known about the details of the transition from desiccation tolerance to avoidance, nor how this took place in conjunction with the 
switch from a gametophyte to a sporophyte-dominated life cycle; yet, these two steps underpin the radiation of vascular plants onto dry land (Puttick et al. 2018; Qiu et al. 2006; Wickett et al. 2014).

Ferns represent an important, understudied group of tracheophytes for investigating both the ecology and evolution of desiccation tolerance. Ferns are the only major lineage among land plants with sporophytes and gametophytes that are capable of growing independently from each other. These two life stages differ drastically in their morphology and physiology-fern sporophytes have true vascular tissue and are homoiohydric (i.e., they regulate their internal water content), whereas fern gametophytes are much smaller (often $<1 \mathrm{~cm}$ ), lack vascular tissue, and are poikilohydric. Recent studies indicate that the gametophytes of many fern species are desiccation tolerant, while sporophytes of the same species are thought to lack DT (Pittermann et al. 2013; Watkins et al. 2007a). Thus, ferns present a unique opportunity to observe the transition from desiccation tolerance to desiccation avoidance across independently growing life stages within a single organism.

Filmy ferns (Hymenophyllaceae) represent a particularly interesting case for studying the ecological and evolutionary significance of vegetative DT across life stages in ferns. Filmy ferns are a large family [c. 430 spp.; Pteridophyte Phylogeny Group I (2016)] of primarily tropical, leptosporangiate ferns named for their remarkably thin leaf laminae, which are usually only a single cell layer in thickness and lack cuticle or stomata (Fig. 1a-d). Filmy fern sporophytes are a remarkable exception to the 'typical' homoiohydric fern sporophyte described above because they have reverted to poikilohydry: their thin laminae allow for passive, rapid uptake and loss of moisture, thereby maintaining nearly constant equilibrium with atmospheric humidity (Raven 1999). Many species of epiphytic filmy ferns have extremely reduced root systems (Schneider 2000), relying completely upon absorption through leaf laminae for water (Shreve 1911), although terrestrial species possess true roots and use ground water (Dubuisson et al. 2011). Thus, the morphological and phys- 
iological gap between sporophytes and gametophytes is arguably smaller in filmy ferns compared to any other fern clade. This makes filmy ferns a potentially useful group for understanding the transition from a desiccation tolerant, gametophyte-dominated strategy to a desiccation avoiding, sporophyte-dominated one, since the sporophytes and gametophytes of ancestral tracheophytes were also likely initially similar, then gradually diverged by a series of step-wise adaptations (Bateman et al. 1998; Ligrone et al. 2012).

Filmy fern sporophytes encompass a broad diversity of growth forms (terrestrial, saxicolous, hemi-epiphytic, and holoepiphytic) and morphologies, with rhizome and leaf sizes varying over an order of magnitude (Dubuisson et al. 2013; Hennequin et al. 2008; Nitta and Epps 2009). As would be expected from their poikilohydric nature, DT of varying degrees has been reported in sporophytes of many filmy fern species (see references below). Filmy fern gametophytes are similarly diverse, with morphotypes including filamentous, ribbon, and a combination of these two types (Fig. 1e-h). While there are no quantitative data about DT in filmy fern gametophytes available, DT has been reported in gametophytes from several other fern lineages (Pittermann et al. 2013; Watkins et al. 2007b; Watkins and Cardelús 2012), and may be expected to occur in filmy ferns as well. The possibility for varying degrees of vegetative DT in both stages of the life cycle of filmy ferns makes them a potentially useful system to compare how DT is utilized between haploid, non-vascular and diploid, vascular life stages. Furthermore, the diversity of growth forms and habitats in filmy ferns makes them an ideal group for a comparative study of water-stress strategies (i.e., desiccation tolerance vs. desiccation avoidance) and their association with different ecological niches (i.e., along gradients of temperature and relative humidity).

The degree of DT in filmy fern sporophytes occupying different niches has been relatively well studied. In a series of elegant experiments on Jamaican filmy ferns, Shreve (1911) demonstrated that water-use strategies differ between species with contrasting growth habits including terrestrial, low elevation epiphyte, and high elevation epiphyte. Proctor 
$(2003,2012)$ investigated water relations and the ability to recover from desiccation in sporophytes of several filmy ferns, and found a general correlation between high DT and adaptation for high light levels in widespread species vs. low DT and adaptation to low light levels in species occupying more sheltered habitats. In the only study to our knowledge including in situ physiological observations of hymenophyllaceous gametophytes, Johnson et al. (2000) found that gametophytes of Vandenboschia speciosa (Willd.) G. Kunkel (= Trichomanes speciosum Willd.) are adapted for extremely low light environments, and operate at lower light levels than conspecific sporophytes. Parra et al. (2009) and Saldaña et al. (2014) investigated the relationship between physiology (photosynthetic rates and water relations) and vertical stratification in several epiphytic filmy fern species (primarily genus Hymenophyllum) along tree trunks in Chile. They found that species occurring at greater heights in the trees tended to have greater DT, higher photosynthetic capacity $\left(A_{\max }\right)$, and lower rates of evapotranspiration. A study using two species of Hymenophyllum demonstrated that DT in filmy ferns likely operates via a homoiochlorophyllous, constitutive mechanism, which is more similar to that of bryophytes than other drought-tolerant vascular plants, thus allowing filmy ferns to adjust to dry conditions extremely rapidly (Cea et al. 2014). This was further supported by evidence that induced biomechanical mechanisms likely do not play a role in DT of filmy ferns (Fallard et al. 2018; but see Mkhize et al. 2020). Recently, transcriptomics has been applied to elucidate the genes involved at each step of the desiccation-recovery cycle of filmy ferns (Ostria-Gallardo et al. 2020a, b). In epiphytic Hymenoglossum cruentum Cav., key genes and gene networks were identified related to intracellular mobility and photosynthetic metabolism in the desiccated state, and those related to detoxifying pathways and stabilization of photosystems during rehydration (Ostria-Gallardo et al. 2020b). In a comparison of low-trunk and canopy epiphytes, Ostria-Gallardo et al. (2020a) identified multiple differentially expressed genes that may be specific to tolerating desiccation in these microhabitats.

Despite this considerable interest in filmy fern ecophysiology, with the sole exception of 
Johnson et al. (2000), no studies have compared physiology between gametophyte and sporophyte stages, and we are aware of none that have done so across multiple species. Furthermore, to our knowledge, no physiological studies of filmy ferns have accounted for their phylogenetic relationships, and we lack an understanding of how physiological strategies have evolved in this clade. In addition to DT, photosynthetic optima (adaptation to different light levels) are likely to be important in determining the niches of life stages and species of filmy ferns (Flores-Bavestrello et al. 2016; Parra et al. 2015; Proctor 2003). Terrestrial and epiphytic species experience different levels of photosynthetic radiation and desiccation, and light intensity varies with height along the host plant in epiphytes (Benzing 1990; Watkins and Cardelús 2009). The combined effect of desiccation and light stress may induce greater oxidative damage in filmy ferns than either of these stressors alone (Niinemets et al. 2018), suggesting the need to integrate studies of DT with photosynthesis to gain a full picture of physiological adaptation in filmy ferns. Here, we leverage a recently developed DNA barcoding system (Nitta et al. 2017) to test several hypotheses related to DT and photosynthesis in a comparative phylogenetic framework including both filmy fern sporophytes and gametophytes: 1.) Light responses and DT differ between species with different growth habits. 2.) Light responses and DT differ between sporophytes and gametophytes. 3.) DT increases with decreasing environmental water availability. 4.) Gametophytes with broader elevational ranges have higher DT than those with with narrower ranges.

\section{Materials and methods}

\section{Study system}

We selected the island of Moorea, French Polynesia ( $17^{\circ} 32^{\prime} \mathrm{S}, 149^{\circ} 50^{\prime} \mathrm{W}$ ) for our survey of filmy fern ecophysiology. Moorea is a small (135 km²; maximum elevation $1206 \mathrm{~m})$ tropical oceanic island, located c. $15 \mathrm{~km} \mathrm{NW}$ of its larger sister island, Tahiti. Despite its 
small size, it hosts a range of habitats including coastal strand, low elevation rainforest, and high elevation cloud forest. A total of 19 filmy fern species are known from Moorea, including multiple terrestrial, saxicolous, and epiphytic species (Florence in press; Murdock and Smith 2003; Nitta et al. 2011b, 2017; Ranker et al. 2005) (Figs 1, S1; all supplemental figures available in Online Resource 1). The two major clades of filmy ferns, the hymenophylloid and trichomanoid lineages (Pryer et al. 2001), are represented on Moorea by 7 and 12 species, respectively. We follow the taxonomic system of Ebihara et al. (2006) for Hymenophyllaceae.

\section{Field survey and DNA barcoding}

We surveyed filmy ferns on Moorea as part of a larger study including all ferns of Moorea and Tahiti (Nitta et al. 2017). During this study, 17 sampling sites were established from $c$. $200 \mathrm{~m}$ to $1200 \mathrm{~m}$ primarily along trails to the summits of three large peaks on Moorea: Mt. Rotui (899 m), Mt. Mouaputa (880 m), and Mt. Tohiea (1206 m). At each site, sporophytes were sampled in a single $10 \mathrm{~m} \times 10 \mathrm{~m}$ plot, and gametophytes sampled in two to three 50 $\mathrm{cm} \times 50 \mathrm{~cm}$ plots located within the sporophyte plot. To estimate abundance of sporophytes, the $10 \mathrm{~m} \times 10 \mathrm{~m}$ plot was subdivided into $252 \mathrm{~m} \times 2 \mathrm{~m}$ subplots, and the presence of species in the sporophyte phase in each subplot was summed such that each species was assigned an abundance rank from 1 to 25 . For the gametophyte plots, each $50 \mathrm{~cm} \mathrm{x}$ $50 \mathrm{~cm}$ plot was subdivided into $255 \times 5 \mathrm{~cm}$ squares, and a single gametophyte selected closest to the center of each square, to later be identified to species using DNA barcoding (see below). Epiphytes were sampled to a maximum height of c. $2 \mathrm{~m}$ on their host plants. For additional details on sampling procedure, see Nitta et al. (2017). The growth habit of each species was scored based on field observations as terrestrial, saxicolous, low elevation epiphyte (mostly occurring outside of cloud forest, i.e., below c. $500 \mathrm{~m}$ ), or high elevation epiphyte (mostly occurring in cloud forest, i.e., above c. 500 m). Crepidomanes bipunctatum (Poir.) Copel. and C. humile (G. Forst.) Bosch were observed growing 
as both epiphytes and saxicoles, but were treated as epiphytes to distinguish them from exclusively saxicolous species.

Unlike sporophytes, fern gametophytes are cryptic and cannot be identified to species based on morphology alone. Therefore, we used DNA barcoding to identify filmy fern gametophytes to species following Nitta et al. (2017). Briefly, DNA extraction was performed using a modified CTAB protocol (Doyle and Doyle 1987) or the Plant Mini DNEasy kit (Qiagen, Valencia, California, USA) following the manufacturer's protocol. Chloroplast rbcL and trnH-psbA were amplified and sequenced using primers and protocols following Nitta et al. (2017). For each marker, a reference library was constructed from sporophyte sequences using the 'makeblastDB' command in BLAST (Altschul et al. 1997). Field-collected gametophytes were identified by a local BLAST query against the reference library. Gametophytes matching $>99.5 \%$ with a single reference sequence and no others were identified as that species; those that did not match any reference sequence or matched $>99.5 \%$ with multiple reference sequences were not identified and excluded from further analysis. For this study, only gametophytes that could be identified as Hymenophyllaceae were used; others were excluded from analysis.

Fieldwork was done under permits issued by the French Polynesian Government (Délégation à la Recherche) and the Haut-commissariat de la République en Polynésie Francaise (Protocole d'Accueil 2012-2014). Voucher specimens were deposited at UC, with duplicates at GH and PAP (abbreviations follow Thiers (2021)).

\section{Microclimate}

We used microclimate data collected by Nitta et al. (2020). This dataset includes relative humidity $(\mathrm{RH})$ and temperature measured every $15 \mathrm{~min}$ from 2013-07-07 to 2014-07-05 at the fern survey sites with Hobo ProV2 dataloggers (Onset Computer Corporation, Bourne, Massachusetts, USA), and vapor pressure deficit (VPD) calculated from these two values. 
The dataloggers were outfitted with radiation shields (RS1 or RS3, Onset Computer Corporation, Bourne, Massachusetts, USA) to prevent direct contact with precipitation and solar radiation, and placed in pairs at each site (one 'epiphytic' datalogger at c. $1.5 \mathrm{~m}$ on a tree, one 'terrestrial' datalogger at $c .10 \mathrm{~cm}$ next to the tree). During the study period, some dataloggers malfunctioned, presumably due to prolonged exposure to high humidity. Any days during which one or more dataloggers failed are excluded from the dataset. One terrestrial datalogger (Mt. Tohiea $393 \mathrm{~m}$ site) was lacking data for more than half of the survey period, but had data available for the same period from a preliminary survey conducted during the previous year (2012-2013), so the previous year's data for this site was used instead. The dataset includes 244 days of data from 15 sites ( 26 dataloggers). Mean daily temperature on Moorea is strongly correlated with elevation, dropping c. $6^{\circ} \mathrm{C}$ from the lowest surveyed site $(201 \mathrm{~m})$ to the highest $(1206 \mathrm{~m})\left(R^{2}=0.87 ; P<0.001\right.$; linear model); temperature does not differ significantly between epiphytic and terrestrial habitats (Nitta et al. 2020). Epiphytic habitats tend to have lower daily mean RH, and greater daily variation in $\mathrm{RH}$, than terrestrial ones. This difference is greatest at low elevations, and smallest at high elevations (Nitta et al. 2020).

\section{Desiccation tolerance}

Samples were collected in the field and stored in plastic bags with a small amount of water to keep them fresh during transport to the lab. For sporophytes, eight individuals (one individual $=$ single whole frond including a c. $2 \mathrm{~cm}$ section of rhizome) were used per treatment, and all individuals for each species came from a single population. We did not attempt to differentiate genotypes between fronds in species with long-creeping rhizomes, which often form clonal mats; hence, in some cases, individuals may be genetically identical ramets. All experiments were initiated within $48 \mathrm{~h}$ of collection. Pre-treatment maximum photochemical yield of photosystem II $\left(F_{v} / F_{m}\right)$ (Kitajima and Butler 1975) was measured in fresh plants after a 10 min period of dark-adaptation using a portable mini- 
PAM chlorophyll fluorometer (Walz Gmbh, Effeltrich, Germany). Any samples with pretreatment $F_{v} / F_{m}<0.4$ were excluded from analysis, as typical values of $F_{v} / F_{m}$ in healthy plants tend to be c. 0.8 (Björkman and Demmig 1987). Samples were then transferred to desiccation chambers containing saturated salts at three different desiccation intensities or a control treatment with moist tissues $(100 \% \mathrm{RH})$, and water withheld for either a short (2 d) or long (15 d) interval (Testo and Watkins 2013). Conditions inside the desiccation chambers were monitored during the experiment using Track-lt RH/Temp dataloggers (Monarch Instrument, Amherst, NH) logging every 10 min (2012 field season for species other than Callistopteris apiifolia (Presl) Copel.) or Hobo ProV2 dataloggers logging every 5 min (2012 C. apiifolia, 2013, 2014 field seasons). The desiccation chambers were kept in an air-conditioned room. Temperature inside the chambers was mean $24.1 \pm$ SD 1.15 ${ }^{\circ} \mathrm{C}$ (Fig. S2) (hereafter, the value following ' \pm ' is standard deviation unless otherwise mentioned). Salts used for desiccation and their corresponding mean water potentials and approximate relative humidity and VPD are as follows: $\mathrm{LiCl}(-282 \mathrm{MPa}, 18 \% \mathrm{RH}, 2.45 \mathrm{kPa})$, $\mathrm{Mg}\left(\mathrm{NO}_{3}\right)_{2}(-86 \mathrm{MPa}, 58 \% \mathrm{RH}, 1.25 \mathrm{kPa})$, and $\mathrm{NaCl}(-38 \mathrm{MPa}, 80 \% \mathrm{RH}, 0.60 \mathrm{kPa})$. Following the desiccation treatment, plants were rewetted by wrapping them in moist tissues using water from a local stream. Plants were allowed to rehydrate, and $F_{v} / F_{m}$ was again measured at $0.5 \mathrm{~h}, 24 \mathrm{~h}$, and $48 \mathrm{~h}$ following rewetting. Ability to recover from desiccation was quantified by comparing pre- and post-treatment $F_{v} / F_{m}$ (Watkins et al. 2007a).

We measured relative water content (RWC) in a subset of samples by recording the mass of samples prior to the DT test (fresh mass), at each step of the DT test (turgid mass), then following the DT test after drying them overnight in an oven at $65^{\circ} \mathrm{C}$ (dry mass). Relative water content was calculated as $R W C=\frac{T M-D M}{F M-D M} \times 100$, where $T M$ is turgid mass, $D M$ is dry mass, and FM is fresh mass.

Because field-collected gametophytes could not be identified to species prior to DNA extraction, no planned replication by species was possible. We therefore applied the same 
treatment for all gametophytes (2 d at -86 MPa) in batches of individuals (Table S1), and verified the species of each individual after the experiment using the DNA barcode approach described above. Thus, gametophytes of some species were sampled many times whereas those of other species were not. Relative water content was not calculated for gametophytes, as these were too small to measure accurately with the balances available.

\section{Light responses}

Rapid light response curves were constructed for each species by measuring photosynthetic yield at gradually increasing levels of photosynthetically active actinic light (400 nm to $700 \mathrm{~nm}$ ) with the Light Curve function of the mini-PAM portable chlorophyll fluorometer as described by the manufacturer. Briefly, the maximum yield $\left(F_{m}\right)$ was first measured in the absence of actinic light. Next, plants were equilibrated to the actinic light for $30 \mathrm{~s}$, and photosynthetic yield $\left(\Delta F / F_{m}\right)$ measured with a $0.8 \mathrm{~s}$ saturating pulse. This was repeated for each photosynthetic photon flux density (PPFD) level, up to ca. $500 \mu \mathrm{mol} \cdot \mathrm{m}^{-2} \cdot \mathrm{s}^{-1}$. Response curves were fitted using the equation $y=A\left(1-e^{-k x}\right)$, where $y$ is relative electron transport rate of photosystem II (RETR), $x$ is photosynthetic photon flux density (PPFD), $A$ is the asymptote of the curve, and $k$ is a slope parameter; outliers at high PPFD likely to distort the curve were discarded (Proctor 2012). The PPFD at $95 \%$ saturation of $\operatorname{RETR}\left(\operatorname{PPFD}_{95 \%}\right)$ and maximum RETR $\left(\right.$ ETR $\left._{\text {max }}\right)$ were then calculated from the curve. Light responses were measured in eight individuals per species in the lab for sporophytes, and on single individuals in the field for gametophytes. The gametophytes were later identified to species using the DNA barcodes.

\section{Statistical analysis}

All statistical analyses were done in R v.4.0.3 (R Core Team 2020).

We derived the phylogenetic tree used in this study by extracting Hymenophyllaceae from 
the tree of Nitta et al. (2017) with the 'extract.clade' function of the 'ape' package (Paradis et al. 2004). This tree is in agreement with previously published, more densely sampled phylogenies (Dubuisson et al. 2003; Ebihara et al. 2007; Hennequin et al. 2006; Pryer et al. 2001).

We quantified the degree of phylogenetic signal in physiological traits using Blomberg's $K$ (Blomberg et al. 2003) and Pagel's $\lambda$ (Freckleton et al. 2002; Pagel 1999) as implemented with the 'phylosig' function in the 'phytools' package (Revell 2012). Both measures test the hypothesis that the trait of interest is evolving according to Brownian Motion (BM). $\lambda$ is a scaling parameter that ranges from zero to one: $\lambda$ near zero indicates random distribution of trait values across the tree, and $\lambda$ near one indicates evolution of traits along the phylogeny following BM. For $K$, values near one indicate evolution of traits following BM; $K>1$ indicates traits more conserved than expected under $\mathrm{BM}$, and $K<1$ indicates that traits have less phylogenetic signal than expected under BM. We tested the significance of $K$ by comparing the observed value against values from a null distribution of 10,000 phylogenies with the traits randomly shuffled across the tips. We tested the significance of $\lambda$ with a log-likelihood test comparing the likelihood of the observed value of $\lambda$ vs. $\lambda$ $=0$. For all further analyses, we used methods that account for phylogenetic history for physiological traits that showed evidence of phylogenetic signal in at least one of the two metrics, and standard methods otherwise.

We used general linear mixed models (GLMMs) to investigate the effect of growth habit and life stage on DT (\% recovery of $\mathrm{F}_{\mathrm{v}} / \mathrm{F}_{\mathrm{m}}$ after $48 \mathrm{~h}$ recovery from desiccation at -86 MPa for $2 \mathrm{~d}$ ) and photosynthetic parameters $\left(\mathrm{ETR}_{\max }\right.$ and PPFD $\left._{95 \%}\right)$ using the 'MCMCglmm' package (Hadfield 2010). For each of the three response variables (species mean DT, ETR $_{\text {max }}$, and PPFD $95 \%$ ), we constructed five models: a null model with no fixed effects, or models with either growth habit (high-elevation epiphyte, low-elevation epiphyte, terrestrial or saxicolous), life stage (sporophyte vs. gametophyte), growth habit and life stage, or 
growth habit, life stage, and their interaction as fixed effects. We included species as a random effect in all models, and included a phylogenetic variance-covariance matrix if the response variable showed evidence of phylogenetic signal (Hadfield 2010). We used an inverse-Gamma distribution for all priors, and ran analyses for 500,000 iterations, with burnin after 1,000 iterations and thinning every 500 iterations. We compared models using the Deviance Information Criterion (DIC) (Spiegelhalter et al. 2002) and selected the bestfitting model as the one with the lowest DIC.

Comparisons of DT, ETR max $_{\text {, and }}$ PPFD $_{95 \%}$ between gametophytes and sporophytes of the same species do not involve phylogeny, so we used a two-sided $t$-test for these.

To test for a correlation between environmental water availability and DT, we first derived a single maximum VPD for each species by calculating the average of the maximum daily VPD at all sites where that species was present. We used maximum VPD (i.e., minimum humidity) values because these may represent a climatic extreme that limits the occurrence of species. We used data from the 'epiphytic' dataloggers mounted at $1.5 \mathrm{~m}$ on trees for epiphytic species and data from the 'terrestrial' dataloggers on the ground for non-epiphytic species. Data from the Mt. Rotui $830 \mathrm{~m}$ site were excluded because this site is much more exposed than the other high elevation sites, and appears as a significant outlier in the microclimatic data (Nitta et al. 2020). Since DT showed significant phylogenetic signal (see Results), we used phylogenetic generalized least squares (PGLS) (Freckleton et al. 2002) to test for a relationship between VPD and DT while taking phylogeny into account, using species' means.

To test whether gametophytes with broader ranges have higher DT, we calculated the extent of gametophyte range beyond sporophytes ("G beyond $S$ ") as the total elevational range $(m)$ gametophytes were observed growing beyond sporophytes at either end of the elevational gradient. We conducted PGLS with DT as the response variable and G beyond S as the explanatory variable with the 'pgls' function in the 'caper' (Orme et al. 2018). 
Datasets used in this study are available on FigShare (https://doi.org/10.6084/m9. figshare.14184572). Code used to analyze the data and generate figures and this manuscript are available on GitHub (https://github.com/joelnitta/moorea_filmies). A Docker image is available to run the code at https://hub.docker.com/r/joelnitta/ moorea_filmies. The 'targets' package (Landau 2021) was used to automate the workflow. The 'ggplot2' (Wickham 2016), 'ggtree', (Yu et al. 2017) and 'patchwork' (https://github.com/thomasp85/patchwork) packages were used to generate the figures.

*** NOTE TO READER: The DOI for the dataset will not be active until the paper is accepted. Until then, this link can be used for the dataset https://figshare.com/s/ d6349abf01a3756a5aae ***

\section{Results}

\section{Field survey}

In total, 22 filmy fern taxa (including two species that were recognized as multiple varieties) were observed on Moorea. Three taxa with distinct rbcL sequences, morphology, and elevational ranges could be distinguished within the Crepidomanes minutum (Blume) K. Iwats. species complex, but species status of these taxa remains uncertain (Nitta et al. 2011a). We refer to these here as $C$. minutum var. 1,2 , and 3 . Similarly, two members of the Abrodictyum asae-grayi (Bosch) Ebihara \& K. Iwats. complex (also including Abrodictyum caudatum (Brack.) Ebihara \& K. Iwats. in our tree; Fig. S1) were observed on the basis of $r b c L$ and morphology, but as taxonomic treatment is beyond the scope of the current study we refer to them as $A$. asae-grayi var. 1 and 2.

In several species, gametophytes exceeded the maximum or minimum elevational range of sporophytes including C. apiifolia, C. minutum var. 2 and 3, Hymenophyllum digitatum (Sw.) Fosberg, Hymenophyllum javanicum Spreng., Hymenophyllum pallidum (Blume) Ebi- 
hara \& K. Iwats., and Polyphlebium borbonicum (Bosch) Ebihara \& Dubuisson (Fig. S3). All of these have sporophytes that are normally restricted to cloud forest (c. 500-1200 m), but gametophytes that are distributed to lower elevations.

Sporophytes of two taxa, C. minutum var. 3 and Hymenophyllum braithwaitei Ebihara \& K. Iwats., did not occur in the study plots, but each was observed from a single population on Mt. Tohiea, at c. $1000 \mathrm{~m}$ and near the summit $(1206 \mathrm{~m})$, respectively. We include these observations for comparison of ranges between sporophytes and gametophytes.

\section{Phylogenetic signal}

For DT, $K$ was near 1 with $P<0.1$ in both life stages (gametophytes $K=0.68, P=0.036$; sporophytes $K=0.69, P=0.053)$; $\lambda$ was near 1 for both life stages, but not significant for sporophytes (gametophytes $\lambda=0.68, P=0.063$; sporophytes $\lambda=0.71, P=0.298$ ). There was no evidence of significant phylogenetic signal in photosynthetic parameters $\left(\right.$ PPFD $_{95 \%}$ and $\left.\mathrm{ETR}_{\mathrm{max}}\right)$ in either life stage $(P » 0.05$, Table 1$)$. Therefore, phylogenetic methods were used for analyses involving DT, but not photosynthetic parameters.

\section{Desiccation tolerance}

Ability to recover from desiccation was tested in sporophytes of 14 species and gametophytes of 14 species, including 12 species with both life stages.

A general correlation of DT with habitat was observed in sporophytes (Fig. 2a). The two terrestrial species lacked DT, although $C$. apiifolia showed slightly greater ability to recover by $48 \mathrm{~h}$ compared to Abrodictyum dentatum (Bosch) Ebihara \& K. Iwats., which completely failed to recover from even the gentlest treatment of $2 \mathrm{~d}$ at $-38 \mathrm{NaCl}$ (more stringent tests were not conducted on $A$. dentatum after confirming its lack of DT at this level). Saxicolous species (Crepidomanes kurzii (Bedd.) Tagawa \& K. Iwats., Polyphlebium endlicherianum (C. Presl) Ebihara \& K. Iwats., and Vandenboschia maxima (Blume) Copel.) also had 
low DT; only C. kurzii was able to recover from desiccation up to $-86 \mathrm{MPa}$ for $2 \mathrm{~d}$ but not more. Nearly all epiphytic species were capable of recovering from desiccation of up to $2 \mathrm{~d}$ at -86 MPa. Crepidomanes bipunctatum, a widespread low-elevation epiphyte, showed the greatest ability to recover from desiccation across all treatments. Interestingly, high-elevation epiphytes Hymenophyllum multifidum (G. Forst.) Sw. and Hymenophyllum polyanthos (Sw.) Sw. could recover from desiccation at -86 or $-282 \mathrm{MPa}$ for 15 d, but not $-38 \mathrm{MPa}$.

Gametophytes of terrestrial species could not tolerate desiccation (mean $48 \mathrm{~h}$ recovery $9.0 \% \pm 0.8 \%, n=2$ species). Levels of DT were in general higher for saxicolous and epiphytic gametophytes, but otherwise did not show a clear pattern (Fig. 2b).

Desiccation tolerance of gametophytes tended to be lower than sporophytes (Fig. 3), and was significantly lower in $C$. apiifolia, $H$. polyanthos, $H$. pallidum, and $H$. digitatum (t-test, $P$ $=0.015,<0.001,0.035$, and $<0.001$, respectively). Only $P$. endlicherianum showed significantly higher DT in gametophytes compared to sporophytes ( $t$-test, $P=0.027)$.

Control samples generally did not show any decrease in $F_{v} / F_{m}$ throughout the duration of the experiment (Fig. S4) and maintained RWC near 100\% (Figs S5, S6). Relative water content in the desiccated state ranged from $5.1 \% \pm 5.2 \%$ ( $n=9$ species) in the $-282 \mathrm{MPa}$, $15 \mathrm{~d}$ treatment to $17.2 \% \pm 8.0 \%$ ( $n=10$ species) in the $-38 \mathrm{MPa}, 2 \mathrm{~d}$ treatment (Fig. S5), and returned to c. $100 \%$ upon re-wetting in all species sampled (Figs S5, S6).

Relative humidity in the growth chambers was high when samples were first inserted, then gradually decreased to the target value maintained by each drying salt (Fig. S2). In a few cases (particularly species with larger fronds, e.g., C. apiifolia), the $\mathrm{NaCl}$ chamber did not reach equilibrium humidity before $2 \mathrm{~d}$ (Fig. S2). Brief fluctuations in humidity were observed when chambers were opened to insert or remove samples (Fig. S2).

The GLMM including the combined effects of life stage plus growth habit and their interaction was selected as the best-fitting model for DT (Table 2). Sporophytes had 52.3\% 
greater DT (95\% Cl $24.1 \%$ to $77.1 \%$ ) relative to gametophytes (Table 3 ).

\section{Photosynthetic optima}

Light responses were measured in sporophytes of 13 species and gametophytes of 10 species, including nine species with both life stages.

Photosynthetic optima showed clear differences across life stages: sporophytes were adapted for higher light levels, whereas gametophytes were adapted for lower light levels (Figs 3, S7, S8). Sporophytes reached their maximum photosynthetic rate $\left(\right.$ PPFD $\left._{95 \%}\right)$ at light levels ca. $144.1 \pm 36.8 \mu \mathrm{mol} \cdot \mathrm{m}^{-2} \cdot \mathrm{s}^{-1}(n=13$ species $)$, whereas gametophytes did so at $71.0 \pm 29.6 \mu \mathrm{mol} \cdot \mathrm{m}^{-2} \cdot \mathrm{s}^{-1}(n=10$ species $)$. Similarly, sporophytes attained higher rates of electron transport $\left(\mathrm{ETR}_{\max }\right)\left(8.6 \pm 3.2 \mu \mathrm{mol} \cdot \mathrm{m}^{-2} \cdot \mathrm{s}^{-1}, n=13\right.$ species$)$ than gametophytes $\left(4.6 \pm 1.6 \mu \mathrm{mol} \cdot \mathrm{m}^{-2} \cdot \mathrm{s}^{-1}, n=10 \mathrm{species}\right)$.

The GLMM including the effect of life stage only was selected as the best-fitting model for $\mathrm{ETR}_{\mathrm{max}}$, and the combined effect of growth habit plus life stage and their interaction was selected for PPFD $_{95 \%}$ (Table 2).

\section{Relationships of vapor pressure deficit and range size with DT}

Desiccation tolerance increased significantly with VPD for sporophytes, but not gametophytes (PGLS, $P=0.038 ;$ Fig. 4; Table 4).

No significant relationship was detected between range size of gametophytes beyond sporophytes and DT (Fig. 4, Table 4).

\section{Discussion}

Vegetative DT was a key innovation linked to the rise of early land plants, but is largely limited to non-vascular groups such as bryophytes and algae among extant plants. Filmy 
ferns have received considerable attention for their remarkable reversion to vegetative DT in the sporophyte stage (e.g., Cea et al. 2014; Ostria-Gallardo et al. 2020a; Proctor 2003; Shreve 1911). Yet, no previous study to our knowledge has evaluated parallel physiology of sporophytes and gametophytes of filmy ferns in relation to DT. Here, we present the first comparisons of physiological parameters between life stages within filmy ferns in a phylogenetic comparative framework.

\section{Filmy fern sporophytes have a wide range of DT}

We identified a wide variation of DT in filmy fern sporophytes on Moorea, from marked sensitivity in terrestrial species to tolerance of water potentials well below -200 MPa (VPD > $2.45 \mathrm{kPa}$ ) in some epiphytes. Levels of similarly extreme DT have also been reported in other species of Hymenophyllum (Proctor 2003, 2012) and a general correlation of habitat with DT in filmy ferns has been previously established (Parra et al. 2009; Proctor 2003, 2012; Saldaña et al. 2014; Shreve 1911), but no other studies to our knowledge have documented a similar range of DT values in filmy ferns from a single site. One may wonder then, what is the adaptive significance of being able to withstand drying at -282 MPa (c. $2.45 \mathrm{kPa}$ ) vs. $-86 \mathrm{MPa}$ (c. $1.25 \mathrm{kPa}$ ) when the ambient VPD is typically < c. $0.10 \mathrm{kPa}$ and only rarely exceeds $>0.50 \mathrm{kPa}$. The recent finding of a constitutive mechanism for DT in filmy ferns (Cea et al. 2014) supports the need for a relatively wide "safety margin," and similar (or even more extreme) levels of constitutive DT are well known in bryophytes (Oliver et al. 1993). The conservative behavior of fern stomata, which lack a response to the plant stress hormone ABA, is well documented (Brodribb and McAdam 2011; McAdam and Brodribb 2012, 2013). It is possible that filmy ferns also behave conservatively with respect to water-stress. We suggest that the variation in DT observed here is relevant because it is correlated with habitat, and likely reflects overall physiological tolerance, not just artificial extremes. For example, sporophytes of some high elevation epiphytes that we surveyed ( $H$. multifidum, $H$. polyanthos) seem to be able to better withstand intense 
vs. moderate desiccation, with higher recovery values at -282 and $-86 \mathrm{MPa}$ vs. $-38 \mathrm{MPa}$ when dry for $15 \mathrm{~d}$. This may be an adaptation to cloud forest conditions; although cloud forests are frequently moist due to constant fog, dry periods are intense during the times when there is no cloud cover (J. Nitta, pers. obs.). The complete lack of DT in terrestrial species is not surprising, considering they have much more direct access to water than epiphytes and therefore are under substantially less selective pressure to maintain DT. Because controls kept at $100 \% \mathrm{RH}$ maintained $\mathrm{F}_{\mathrm{v}} / \mathrm{F}_{\mathrm{m}}$ values near pre-treatment levels in all sporophytes (Fig. S4), it is unlikely that the lack of tolerance seen in terrestrial species is solely due to removal from the soil. The significant relationship between average daily maximum VPD and DT in sporophytes supports the specialization of sporophyte DT according to niche, and indicates that sporophytes of non-tolerant terrestrial and saxicolous species may be unable to occur in habitats with VPD exceeding c. $0.1 \mathrm{kPa}$ (Fig. 4).

\section{Filmy fern gametophytes are not more stress-tolerant than sporophytes}

Contrary to our hypotheses, gametophytes of filmy ferns are in general not more tolerant of the abiotic environment (light levels and water potential) than sporophytes. This differs from other fern groups with desiccation tolerant gametophytes but desiccation avoiding sporophytes (Watkins et al. 2007a). In the filmy ferns we studied, DT levels of both sporophytes and gametophytes largely reflected habitat; in general, epiphytic species tended to have higher DT than terrestrial species, regardless of life stage (Figs 3, S8). Interestingly, this echoes much earlier field observations (not experimental data) by Holloway (1930) on filmy fern gametophytes in New Zealand: he reported apparent DT in gametophytes of Hymenophyllum rarum $\mathrm{R}$. Br. and $\mathrm{H}$. villosum Colenso, both high elevation epiphytes with desiccation tolerant sporophytes, and lack of DT in terrestrial filamentous gametophytes of Polyphlebium colensoi (Hook. f.) Ebihara \& K. Iwats., Abrodictyum strictum (Menzies ex Hook. \& Grev.) Ebihara \& K. Iwats., and A. elongatum (A. Cunn.) Ebihara \& K. Iwats. occupying moist, protected sites on the forest floor. Watkins et al. (2007a) also 
found that DT of fern gametophytes tended to match habitat, with terrestrial species having lower DT than epiphytes. However, we found that gametophytes had lower DT than sporophytes regardless of growth habit (Figs 3, S8). At high elevation sites (i.e., cloud forest), epiphytic ferns often occur in a dense matrix of bryophytes (Fig. 1b). It is possible that this bryophyte cover helps to retain moisture during brief periods of drought and thus protect the epiphytic fern gametophytes that grow amongst them (Harrington and Watts 2021). More detailed studies of the high elevation epiphytic environment and interactions between co-occurring gametophytes of ferns and bryophytes are required to test this hypothesis.

Although we predicted that species with gametophytes that occur far beyond the range of their sporophytes would have higher DT, this was not the case (Fig. 4c). This is perhaps best illustrated by C. apiifolia (Fig. 1d, e, h). Sporophytes of this species are usually restricted to moist cloud forest sites from c. $600 \mathrm{~m}$ to $1200 \mathrm{~m}$, but we observed gametophytes over a much wider range, down to $200 \mathrm{~m}$ (Fig. S3). A similar distribution pattern has been reported in congeneric Callistopteris baldwinii (D. C. Eaton) Copel. from Hawaii (Dassler and Farrar 1997). Since gametophytes of C. apiifolia are common on Moorea and have a unique morphology (Nitta et al. 2017), we were able to collect sufficient material of this species for additional tests of DT at 100\% RH for $2 \mathrm{~d}$. However, C. apiifolia gametophytes still failed to recover from even this gentle treatment (Fig. S9). This suggests that the widespread gametophytes of $C$. apiifolia do not rely on DT to attain their distribution, but instead must do so via some other mechanism. Although we measured terrestrial microhabitats by positioning sensors a few $\mathrm{cm}$ above the ground, these sensors are still outside of the boundary layer. It is likely that the gametophytes of $C$. apiifolia do not actually experience the conditions measured with our 'terrestrial' dataloggers, but instead grow within a more consistently moist boundary layer. Gametophytes of C. apiifolia produce gemmae (Fig. 1e, h), and often form dense clonal mats. In the case that their microhabitats do become too dry, they may suffer loss at the edge of the popula- 
tion, then recover by clonal growth (Farrar et al. 2008). Furthermore, the complex surface of clonal mats has been shown to increase the boundary layer and decrease evaporation rates in mosses (Rice et al. 2001), and may function similarly in C. apiifolia. Other filmy fern species also produce gemmae, but they are much more frequent in $C$. apiifolia, and the large size of the clonal mats formed by $C$. apiifolia indicate that it may have a high growth rate (J. Nitta, pers. obs.). It is possible that there is a tradeoff between growth rate and DT, such that species capable of rapid asexual growth like $C$. apiifolia are less able to tolerate desiccation, but slower growing epiphytes such as Hymenophyllum spp. can better tolerate it (Oliver et al. 2000). Growth rates of tolerant versus non-tolerant gametophytes, including quantification of gemmae production, should be investigated in these species to test this hypothesis.

\section{Gametophytes are adapted for lower light levels than sporophytes}

We observed a clear difference between life stages in photosynthetic optima, with gametophytes consistently adapted for lower light levels than sporophytes (Fig. 3, Table 2). In the only other study to our knowledge that compared photosynthetic rates between gametophytes and sporophytes of a filmy fern, Johnson et al. (2000) also found that gametophytes of $V$. speciosa reached maximum ETR at lower levels than sporophytes: in gametophytes of this species, photosynthesis became saturated at a PPFD of $4-5 \mu \mathrm{mol} \cdot \mathrm{m}^{-2} \cdot \mathrm{s}^{-1}$ in the field or $30-50 \mu \mathrm{mol} \cdot \mathrm{m}^{-2} \cdot \mathrm{s}^{-1}$ in the lab vs. $30-50 \mu \mathrm{mol} \cdot \mathrm{m}^{-2} \cdot \mathrm{s}^{-1}$ for sporophytes (lab measurement only). Although we found similar differences in direction between gametophytes and sporophytes, the measurements of Johnson et al. (2000) are considerably lower than what we observed in the field for both Moorean filmy fern gametophytes PPFD $_{95 \%}$ c. $40-$ $60 \mu \mathrm{mol} \cdot \mathrm{m}^{-2} \cdot \mathrm{s}^{-1}$ ) and sporophytes $\left(\mathrm{PPFD}_{95 \%}\right.$ c. $130-160 \mu \mathrm{mol} \cdot \mathrm{m}^{-2} \cdot \mathrm{s}^{-1}$ ). This makes sense in light of the fact that $V$. speciosa is an extremely deep-shade plant, with gametophytes occupying protected rock crevices that receive less than $1 \mu \mathrm{mol} \cdot \mathrm{m}^{-2} \cdot \mathrm{s}^{-1} \mathrm{PPFD}$ for most of the day (Johnson et al. 2000); many of the gametophytes sampled in our study occur in 
more exposed conditions. It is surprising, however, that we did not observe any consistent differences between species in different habitats, given that light levels should vary between tree trunks and the forest floor, at least on a c. $1 \mathrm{~m}$ scale. Although the GLMM showed an interaction effect between life stage and growth habit for PPFD ${ }_{95 \%}$, the model including only life stage was selected for $\operatorname{ETR}_{\max }$ (Table 2). It is possible that the actual light levels experienced by gametophytes growing in these habitats may not vary significantly if they occupy protected microsites such as bryophyte mats or crevices in rock or bark.

\section{Influence of phylogeny on traits}

Previous studies of filmy fern ecophysiology also found a link between habitat and DT and/or photosynthetic rates (Parra et al. 2009; Proctor 2003, 2012; Saldaña et al. 2014); however, ours is the first to our knowledge to investigate this pattern while taking phylogeny into account. We detected phylogenetic signal in DT (Table 1), suggesting that phylogeny should be considered when interpreting differences in DT between species. In contrast, the lack of phylogenetic signal in photosynthetic traits, coupled with the clear differences in traits between life stages, suggest that sporophytes and gametophytes are adapted for different light levels regardless of clade or growth habit. In a more densely sampled study of morphological evolution in the trichomanoid clade, Dubuisson et al. (2013) identified several morphological changes including reduced stele and root systems associated with the evolution of epiphytic growth within the HE subclade (comprising the genera Polyphlebium, Didymoglossum, Crepidomanes, and Vandenboschia). It is possible that both reduced morphology and increased DT are parts of an integrated adaptive strategy for epiphytic growth within this subclade of filmy ferns, and have evolved together repeatedly. However, Dubuisson et al. (2013) were unable to determine if these morphological changes had occurred independently, or if there was a single origin at the base of the HE clade followed by multiple losses. Increased sampling of both morphological 
and physiological traits of additional trichomanoid taxa is needed to distinguish between these competing scenarios.

\section{Concluding remarks and future directions}

In filmy ferns, both sporophyte and gametophyte life stages are poikilohydric; however, this does not necessarily mean they share similar physiological optima. Although filmy fern sporophytes are often of small stature, elevating a leaf even a few $\mathrm{cm}$ above the substrate surface means escape from the boundary layer and exposure to substantially greater evapotranspiration. It is likely that even in this clade, wherein the physiological divide between sporophyte and gametophyte is probably the smallest amongst ferns, the two life stages experience substantially different selective pressures. Fossils indicate that some of the earliest vascular plants may have had sporophytes and gametophytes that were both branched and small (Kenrick and Crane 1997), but it is unclear at what point selective pressures began to diverge to favor large, complex sporophytes and small, simple gametophytes. The relevance of plant size to water relations is supported by a study showing increased DT in smaller size classes of the epiphytic fern Asplenium auritum Sw. (Testo and Watkins 2012). Future studies of DT in filmy ferns should include juvenile stages of the sporophyte, which are expected to experience similar microhabitats as gametophytes, to better determine the role of microhabitat vs. life stage (and plant size) on DT. The recent application of transcriptomics to filmy fern ecophysiology has begun to reveal the genetic mechanisms underlying DT in these plants (Ostria-Gallardo et al. 2020a, b). Future studies that apply such methods to gametophytes as well as sporophytes across a variety of growth habits are anticipated to provide even greater insight into the ecology and evolution of filmy ferns as well as the transition from desiccation tolerance to avoidance in vascular plants.

\section{Acknowledgments}


Members of the Davis Lab and Jonathan Losos provided helpful discussion and comments on drafts. Saad Amer, Ravahere Taputuarai, Tohei Theophilus, and Suzanne Vinnette assisted with fieldwork and experiments. Weston Testo provided advice on settings for the DT test. Two anonymous reviewers provided feedback that improved the manuscript. Staff at the University of California Berkeley's Richard B. Gump South Pacific Research Station, Moorea, French Polynesia, in particular Valentine Brotherson, Neil Davies, Hinano Teavai-Murphy, and Frank Murphy, provided logistical support for fieldwork. Funding provided in part by the National Science Foundation (Doctoral Dissertation Improvement Grant DEB-1311169 to JHN and CCD), Setup Funds from Harvard University to CCD, American Society of Plant Taxonomists (Research Grant for Graduate Students to JHN), Garden Club of America (Award in Tropical Botany to JHN), Harvard University Herbaria (Fernald Fieldwork Fellowship to JHN), Society of Systematic Biologists (Graduate Student Research Award to JHN), and Systematics Association (Systematics Research Fund to JHN).

\section{References}

Altschul SF, Madden TL, Schäffer AA, et al (1997) Gapped BLAST and PSI-BLAST: A new generation of protein database search programs. Nucleic Acids Res 25:3389-3402. doi: $10.1093 /$ nar/25.17.3389

Bateman RM, Crane PR, DiMichele WA, et al (1998) Early evolution of land plants: Phylogeny, physiology, and ecology of the primary terrestrial radiation. Annu Rev Ecol Syst 29:263-292. doi: 10.1146/annurev.ecolsys.29.1.263

Benzing DH (1990) Vascular epiphytes: General biology and related biota. Cambridge University Press, Cambridge, UK

Björkman O, Demmig B (1987) Photon yield of $\mathrm{O}_{2}$ evolution and chlorophyll fluorescence characteristics at $77 \mathrm{~K}$ among vascular plants of diverse origins. Planta 170:489-504. 
doi: $10.1007 / b f 00402983$

Blomberg SP, Garland Jr. T, Ives AR (2003) Testing for phylogenetic signal in comparative data: Behavioral traits are more labile. Evolution 57:717-745. doi: 10.1111/j.00143820.2003.tb00285.x

Brodribb TJ, McAdam SAM (2011) Passive origins of stomatal control in vascular plants. Science 331:582-585. doi: 10.1126/science.1197985

Cea MG, Claverol S, Castillo CA, et al (2014) Desiccation tolerance of Hymenophyllacea filmy ferns is mediated by constitutive and non-inducible cellular mechanisms. C R Biol 337:235-243. doi: 10.1016/j.crvi.2014.02.002

Dassler CL, Farrar DR (1997) Significance of form in fern gametophytes: Clonal, gemmiferous gametophytes of Callistopteris baueriana (Hymenophyllaceae). Int J Plant Sci 158:622-639. doi: $10.1086 / 297476$

Doyle JJ, Doyle JL (1987) A rapid DNA isolation procedure for small quantities of fresh leaf tissue. Phytochem Bull 19:11-15. doi: 10.2307/4119796

Dubuisson J-Y, Bary S, Ebihara A, et al (2013) Epiphytism, anatomy and regressive evolution in trichomanoid filmy ferns (Hymenophyllaceae). Bot J Linn Soc 173:573-593. doi: $10.1111 /$ boj.12106

Dubuisson J-Y, Hennequin S, Bary S, et al (2011) Anatomical diversity and regressive evolution in trichomanoid filmy ferns (Hymenophyllaceae): A phylogenetic approach. C R Biol 334:880-895. doi: 10.1016/j.crvi.2011.07.009

Dubuisson J-Y, Hennequin S, Douzery EJP, et al (2003) rbcL phylogeny of the fern genus Trichomanes (Hymenophyllaceae), with special reference to neotropical taxa. Int J Plant Sci 164:753-761. doi: 10.1086/377059

Ebihara A, Dubuisson J-Y, Iwatsuki K, et al (2006) A taxonomic revision of Hymenophyl- 
laceae. Blumea 51:221-280. doi: 10.3767/000651906X622210

Ebihara A, Iwatsuki K, Ito M, et al (2007) A global molecular phylogeny of the fern genus Trichomanes (Hymenophyllaceae) with special reference to stem anatomy. Bot J Linn Soc 155:1-27. doi: 10.1111/j.1095-8339.2007.00684.x

Fallard A, Rabert C, Reyes-Díaz M, et al (2018) Compatible solutes and metabolites accumulation does not explain partial desiccation tolerance in Hymenoglossum Cruentum and Hymenophyllum Dentatum (Hymenophyllaceae) two filmy ferns with contrasting vertical distribution. Environ Exp Bot 150:272-279. doi: 10.1016/j.envexpbot.2018.02.002

Farrar DR, Dassler CL, Watkins JE Jr, Skelton C (2008) Gametophyte ecology. In: Haufler $\mathrm{CH}$, Ranker TA (eds) Biology and evolution of ferns and lycophytes. Cambridge University Press, Cambridge, UK, pp 222-256

Florence $\mathrm{J}$ (In press) Flore de la Polynésie française. Volume 3. Fougères et alliés. Editions de l'IRD, Collection Faune et Flore tropicales, Paris, France

Flores-Bavestrello A, Król M, Ivanov AG, et al (2016) Two Hymenophyllaceae species from contrasting natural environments exhibit a homoiochlorophyllous strategy in response to desiccation stress. J Plant Physiol 191:82-94. doi: 10.1016/j.jplph.2015.12.003

Freckleton RP, Harvey PH, Pagel M (2002) Phylogenetic analysis and comparative data: A test and review of evidence. Am Nat 160:712-726. doi: 10.1086/343873

Graham LE (1993) Origin of land plants. John Wiley \& Sons, Inc., New York, New York, USA Hadfield JD (2010) MCMC methods for multi-response generalized linear mixed models: The MCMCglmm R package. J Stat Softw 33:1-22. doi: 10.18637/jss.v033.i02 Harrington AD, Watts JL (2021) Low trunk epiphytic fern gametophyte and sporophyte occurrence is influenced by moss height and density in a Costa Rican lowland tropical 
rainforest. Int J Plant Sci. doi: 10.1086/713443

Hartung W, Schiller P, Dietz K-J (1998) Physiology of Poikilohydric Plants. In: Behnke HD, Esser K, Kadereit JW, et al. (eds) Progress in Botany: Genetics Cell Biology and Physiology Ecology and Vegetation Science. Springer, Berlin, Heidelberg, pp 299-327 Hennequin S, Ebihara A, Ito M, et al (2006) New insights into the phylogeny of the genus Hymenophyllum s.l. (Hymenophyllaceae): Revealing the polyphyly of Mecodium. Syst Bot 31:271-284. doi: 10.1600/036364406777585775

Hennequin S, Schuettpelz E, Pryer KM, et al (2008) Divergence times and the evolution of epiphytism in filmy ferns (Hymenophyllaceae) revisited. Int J Plant Sci 169:12781287. doi: $10.1086 / 591983$

Holloway JE (1930) The experimental cultivation of the gametophytes of Hymenophyllum pulcherrimum, Col. and of Trichomanes reniforme, Forst. f. Ann Bot 44:269-284. doi: 10.1093/oxfordjournals.aob.a090218

Johnson GN, Rumsey FJ, Headley AD, Sheffield E (2000) Adaptations to extreme low light in the fern Trichomanes speciosum. New Phytol 148:423-431. doi: 10.1046/j.14698137.2000.00772.x

Kappen L, Valladares F (2007) Opportunistic growth and desiccation tolerance: The ecological success of poikilohydrous autotrophs. In: Pugnaire FI, Valladares F (eds) Functional plant ecology. Taylor and Francis, New York, pp 7-66

Kenrick P, Crane PR (1997) The origin and early evolution of plants on land. Nature 389:3339. doi: $10.1038 / 37918$

Kitajima M, Butler WL (1975) Quenching of chlorophyll fluorescence and primary photochemistry in chloroplasts by dibromothymoquinone. Biochimica et Biophysica Acta (BBA) - Bioenergetics 376:105-115. doi: 10.1016/0005-2728(75)90209-1 
Landau WM (2021) The targets R package: A dynamic Make-like function-oriented pipeline toolkit for reproducibility and high-performance computing. J Open Source Softw 6:2959. doi: 10.21105/joss.02959

Ligrone R, Duckett JG, Renzaglia KS (2012) Major transitions in the evolution of early land plants: A bryological perspective. Ann Bot 109:851-871. doi: 10.1093/aob/mcs017

McAdam SAM, Brodribb TJ (2012) Fern and lycophyte guard cells do not respond to endogenous abscisic acid. Plant Cell 24:1510-1521. doi: 10.1105/tpc.112.096404

McAdam SAM, Brodribb TJ (2013) Ancestral stomatal control results in a canalization of fern and lycophyte adaptation to drought. New Phytol 198:429-441. doi: 10.1111/nph.12190

Mishler BD, Churchill SP (1985) Transition to a land flora: Phylogenetic relationships of the green algae and bryophytes. Cladistics 1:305-328. doi: 10.1111/j.10960031.1985.tb00431.x

Mkhize KGW, Minibayeva F, Beckett RP (2020) Induction of desiccation tolerance mechanisms occurs in both the fast-drying filmy fern Crepidomanes inopinatum and the slow-drying fern Loxogramme abyssinica. S Afr J Bot 131:131-137. doi: 10.1016/j.sajb.2020.02.014

Murdock AG, Smith AR (2003) Pteridophytes of Moorea, French Polynesia, with a new species, Tmesipteris gracilis (Psilotaceae). Pac Sci 57:253-265. doi: $10.1353 /$ psc. 2003.0024

Niinemets Ülo, Bravo LA, Copolovici L (2018) Changes in photosynthetic rate and stress volatile emissions through desiccation-rehydration cycles in desiccation-tolerant epiphytic filmy ferns (Hymenophyllaceae). Plant Cell Environ 41:1605-1617. doi: $10.1111 /$ pce. 13201

Nitta JH, Ebihara A, Ito M (2011a) Reticulate evolution in the Crepidomanes min- 
utum species complex (Hymenophyllaceae). Am J Bot 98:1782-1800. doi: 10.3732/ajb.1000484

Nitta JH, Epps MJ (2009) Hemi-epiphytism in Vandenboschia collariata (hymenophyllaceae). Brittonia 61:392-397. doi: 10.1007/s12228-009-9097-5

Nitta JH, Meyer J-Y, Smith AR (2011b) Pteridophytes of Mo'orea, French Polynesia: Additional new records. Am Fern J 101:36-49. doi: 10.1640/0002-8444-101.1.36

Nitta JH, Meyer J-Y, Taputuarai R, Davis CC (2017) Life cycle matters: DNA barcoding reveals contrasting community structure between fern sporophytes and gametophytes. Ecol Monogr 87:278-296. doi: 10.1002/ecm.1246

Nitta JH, Watkins JE, Davis CC (2020) Life in the canopy: Community trait assessments reveal substantial functional diversity among fern epiphytes. New Phytol 227:18851899. doi: 10.1111/nph.16607

Oliver MJ, Mishler BD, Quisenberry JE (1993) Comparitive measures of desiccationtolerance in the Tortula ruralis complex. I. Variation in damage control and repair. Am J Bot 80:127-136. doi: 10.1002/j.1537-2197.1993.tb13779.x

Oliver MJ, Tuba Z, Mishler BD (2000) The evolution of vegetative desiccation tolerance in land plants. Plant Ecol 151:85-100. doi: 10.1023/A:1026550808557

Oliver MJ, Velten J, Mishler BD (2005) Desiccation tolerance in bryophytes: A reflection of the primitive strategy for plant survival in dehydrating habitats? Integr Comp Biol 45:788-799. doi: 10.1093/icb/45.5.788

Orme D, Freckleton R, Thomas G, et al (2018) Caper: Comparative analyses of phylogenetics and evolution in r. Version 1.0.1. https://CRAN.R-project.org/package=caper

Ostria-Gallardo E, Larama G, Berríos G, et al (2020a) A comparative gene co-expression analysis using self-organizing maps on two congener filmy ferns identifies specific 
desiccation tolerance mechanisms associated to their microhabitat preference. BMC Plant Biol 20:56. doi: 10.1186/s12870-019-2182-3

Ostria-Gallardo E, Larama G, Berríos G, et al (2020b) Decoding gene networks modules that explain the recovery of Hymenoglossum cruentum Cav. after extreme desiccation. Front Plant Sci 11: doi: 10.3389/fpls.2020.00574

Pagel M (1999) Inferring the historical patterns of biological evolution. Nature 401:877884. doi: $10.1038 / 44766$

Paradis E, Claude J, Strimmer K (2004) APE: Analyses of phylogenetics and evolution in R language. Bioinformatics 20:289-290. doi: 10.1093/bioinformatics/btg412

Parra MJ, Acuña K, Corcuera LJ, Saldaña A (2009) Vertical distribution of Hymenophyllaceae species among host tree microhabitats in a temperate rain forest in Southern Chile. J Veg Sci 20:588-595. doi: 10.1111/j.1654-1103.2009.01078.x

Parra MJ, Acuña KI, Sierra-Almeida A, et al (2015) Photosynthetic light responses may explain vertical distribution of Hymenophyllaceae species in a temperate rainforest of southern Chile. Plos One 10:e0145475. doi: 10.1371/journal.pone.0145475

Pittermann J, Brodersen C, Watkins JE Jr (2013) The physiological resilience of fern sporophytes and gametophytes: Advances in water relations offer new insights into an old lineage. Front Plant Sci 4:285. doi: 10.3389/fpls.2013.00285

Proctor MCF (2003) Comparative ecophysiological measurements on the light responses, water relations and desiccation tolerance of the filmy ferns Hymenophyllum wilsonii Hook. and H. tunbrigense (L.) Smith. Ann Bot 91:717-727. doi: 10.1093/aob/mcg077

Proctor MCF (2012) Light and desiccation responses of some Hymenophyllaceae (filmy ferns) from Trinidad, Venezuela and New Zealand: Poikilohydry in a lightlimited but low evaporation ecological niche. Ann Bot 109:1019-1026. doi: $10.1093 / \mathrm{aob} / \mathrm{mcs} 012$ 
Pryer KM, Smith AR, Hunt JS, Dubuisson J-Y (2001) rbcL data reveal two monophyletic groups of filmy ferns (Filicopsida: Hymenophyllaceae). Am J Bot 88:1118-1130. doi: $10.2307 / 2657095$

Pteridophyte Phylogeny Group I (2016) A community-derived classification for extant lycophytes and ferns. J Syst Evol 54:563-603. doi: 10.1111/jse.12229

Puttick MN, Morris JL, Williams TA, et al (2018) The interrelationships of land plants and the nature of the ancestral embryophyte. Curr Biol 28:733-745.e2. doi: 10.1016/j.cub.2018.01.063

Qiu Y, Li L, Wang B, et al (2006) The deepest divergences in land plants inferred from phylogenomic evidence. Proc Natl Acad Sci 103:15511. doi: 10.1073/pnas.0603335103

R Core Team (2020) R: A language and environment for statistical computing. Version 4.0.3. R Foundation for Statistical Computing, Vienna, Austria. https://www.R-project. org/

Ranker TA, Trapp PG, Smith AR, et al (2005) New records of lycophytes and ferns from Moorea, French Polynesia. Am Fern J 95:126-127. doi: 10.1640/00028444(2005)095[0126:SN]2.0.CO;2

Raven JA (1999) The size of cells and organisms in relation to the evolution of embryophytes. Plant Biol 1:2-12. doi: 10.1055/s-2007-978482

Revell LJ (2012) Phytools: An R package for phylogenetic comparative biology (and other things). Methods Ecol Evol 3:217-223. doi: 10.1111/j.2041-210X.2011.00169.x

Rice SK, Collins D, Anderson AM (2001) Functional significance of variation in bryophyte canopy structure. Am J Bot 88:1568-1576. doi: 10.2307/3558400

Saldaña A, Parra MJ, Flores-Bavestrello A, et al (2014) Effects of forest successional status on microenvironmental conditions, diversity, and distribution of filmy fern 
species in a temperate rainforest. Plant Species Biol 29:253-262. doi: 10.1111/14421984. 12020

Schneider H (2000) Morphology and anatomy of roots in the filmy fern tribe Trichomaneae H. Schneider (Hymenophyllaceae, Filicatae) and the evolution of rootless taxa. Bot J Linn Soc 132:29-46. doi: 10.1111/j.1095-8339.2000.tb01853.x

Scott P (2000) Resurrection plants and the secrets of eternal leaf. Ann Bot 85:159-166. doi: 10.1006/anbo.1999.1006

Shreve F (1911) Studies on Jamaican Hymenophyllaceae. Bot Gaz 51:184-209. doi: $10.1086 / 330473$

Spiegelhalter DJ, Best NG, Carlin BP, van der Linde A (2002) Bayesian measures of model complexity and fit. J Royal Statistical Soc B 64:583-639. doi: 10.1111/14679868.00353

Testo WL, Watkins JE Jr (2012) Influence of plant size on the ecophysiology of the epiphytic fern Asplenium auritum (Aspleniaceae) from Costa Rica. Am J Bot 99:18401846. doi: 10.3732/ajb.1200329

Testo WL, Watkins JE Jr (2013) Understanding mechanisms of rarity in pteridophytes: Competition and climate change threaten the rare fern Asplenium scolopendrium var. americanum (Aspleniaceae). Am J Bot 100:2261-2270. doi: 10.3732/ajb.1300150

Thiers B (2021) Index Herbariorum: A global directory of public herbaria and associated staff. http://sweetgum.nybg.org/science/ih/. Accessed 1 Mar 2021

Waters ER (2003) Molecular adaptation and the origin of land plants. Mol Phylogenet Evol 29:456-463. doi: 10.1016/j.ympev.2003.07.018

Watkins JE Jr, Cardelús CL (2009) Habitat differentiation of ferns in a lowland tropical rain forest. Am Fern J 99:162-175. doi: 10.1640/0002-8444-99.3.162 
Watkins JE Jr, Cardelús CL (2012) Ferns in an angiosperm world: Cretaceous radiation into the epiphytic niche and diversification on the forest floor. Int J Plant Sci 173:695-710. doi: $10.1086 / 665974$

Watkins JE Jr, Mack MC, Sinclair TR, Mulkey SS (2007a) Ecological and evolutionary consequences of desiccation tolerance in tropical fern gametophytes. New Phytol 176:708-717. doi: 10.1111/j.1469-8137.2007.02194.x

Watkins JE Jr, Mack MK, Mulkey SS (2007b) Gametophyte ecology and demography of epiphytic and terrestrial tropical ferns. Am J Bot 94:701-708. doi: 10.3732/ajb.94.4.701

Wickett NJ, Mirarab S, Nguyen N, et al (2014) Phylotranscriptomic analysis of the origin and early diversification of land plants. Proc Natl Acad Sci 111:E4859-E4868. doi: 10.1073/pnas. 1323926111

Wickham H (2016) Ggplot2: Elegant Graphics for Data Analysis, 2nd ed. 2016. Springer, New York, NY

Yu G, Smith DK, Zhu H, et al (2017) GGTREE : An R package for visualization and annotation of phylogenetic trees with their covariates and other associated data. Methods Ecol Evol 8:28-36. doi: 10.1111/2041-210x.12628 


\section{Tables}

Table 1 Results of tests for phylogenetic signal (Blomberg's $K$ and Pagel's $\lambda$ ) in desiccation tolerance (DT) and photosynthetic parameters of filmy ferns from Moorea, French Polynesia by life stage

\begin{tabular}{llll}
\hline$K$ & $P(K)$ & $\lambda$ & $P(\lambda)$ \\
\hline
\end{tabular}

\section{Sporophytes}

$\begin{array}{lllll}\text { Recovery } & 0.686 & 0.053 & 0.708 & 0.298 \\ \text { ETR }_{\max } & 0.349 & 0.469 & 7.23 \mathrm{e}-05 & 1.000 \\ \text { PPFD }_{95 \%} & 0.300 & 0.652 & 0.115 & 0.706\end{array}$

\section{Gametophytes}

$\begin{array}{lllll}\text { Recovery } & 0.680 & 0.036 & 0.680 & 0.063 \\ \text { ETR }_{\text {max }} & 0.217 & 0.895 & 7.26 \mathrm{e}-05 & 1.000 \\ \text { PPFD }_{95 \%} & 0.404 & 0.501 & 7.26 \mathrm{e}-05 & 1.000\end{array}$

Recovery, recovery of $\mathrm{F}_{\mathrm{v}} / \mathrm{F}_{\mathrm{m}}(\%)$ following $2 \mathrm{~d}$ desiccation at $-86 \mathrm{MPa}$; $E T R_{\text {max }}$, maximum relative electron transport rate; $\mathrm{PPFD}_{95 \%}$, light level at which $95 \%$ of $\mathrm{ETR}_{\max }$ is reached. 
Table 2 Deviance information criterion (DIC) and delta DIC for general linear mixed models (GLMMs) of photosynthetic parameters and desiccation tolerance in response to life stage and growth habit in filmy ferns from Moorea, French Polynesia

\begin{tabular}{lll}
\hline Fixed effects & DIC & delta DIC \\
\hline ETR $_{\text {max }}$ & & \\
$\quad$ Life stage & $\mathbf{1 1 2 . 3 9}$ & $\mathbf{0 . 0 0}$ \\
Life stage + habit & 114.52 & 2.13 \\
Life stage + habit + Life stage:habit & 115.69 & 3.30 \\
Null & 122.68 & 10.29 \\
Habit & 125.55 & 13.16 \\
PPFD & & \\
Life stage + habit + Life stage:habit & $\mathbf{2 1 1 . 0 5}$ & $\mathbf{0 . 0 0}$ \\
Life stage & 230.46 & 19.42 \\
Life stage + habit & 232.97 & 21.93 \\
Null & 248.08 & 37.04 \\
Habit & 251.78 & 40.73 \\
Recovery & & \\
Life stage + habit + Life stage:habit & $\mathbf{8 . 0 1}$ & $\mathbf{0 . 0 0}$ \\
Life stage & 16.36 & 8.35 \\
Life stage + habit & 16.77 & 8.76 \\
Habit & 23.28 & 15.27 \\
Null & 23.39 & 15.38 \\
\hline
\end{tabular}

$\mathrm{ETR}_{\max }$, maximum relative electron transport rate; $\mathrm{PPFD}_{95 \%}$, light level at which $95 \%$ of ETR $_{\text {max }}$ is reached; Recovery, recovery of $\mathrm{F}_{\mathrm{v}} / \mathrm{F}_{\mathrm{m}}(\%)$ following $2 \mathrm{~d}$ desiccation at $-86 \mathrm{MPa}$ Best model (that with the lowest DIC) for each response variable in bold 
Table 3 Predictor effects, lower and upper 95\% confidence interval (Cl), effective sample size, and significance of model parameters for the best general linear mixed models (GLMMs) of photosynthetic parameters and desiccation tolerance in response to life stage and growth habit in filmy ferns from Moorea, French Polynesia

\begin{tabular}{|c|c|c|c|c|c|c|}
\hline Fixed effects & Predictor & Mean effect & Lower 95\% Cl & Upper $95 \% \mathrm{Cl}$ & Ef. sample size & $P \mathrm{MCMC}$ \\
\hline \multicolumn{7}{|l|}{$\mathrm{ETR}_{\text {max }}$} \\
\hline Life stage & Sporophyte & 3.880 & 1.595 & 6.180 & 997 & 0.002 \\
\hline \multicolumn{7}{|l|}{ PPFD $_{95 \%}$} \\
\hline Life stage + habit + Life stage:habit & Low Epiphyte & -9.964 & -53.576 & 35.593 & 998 & 0.653 \\
\hline Life stage + habit + Life stage:habit & Saxicolous & 55.087 & 5.859 & 106.377 & 997 & 0.034 \\
\hline Life stage + habit + Life stage:habit & Terrestrial & 0.133 & -44.127 & 49.057 & 997 & 0.998 \\
\hline Life stage + habit + Life stage:habit & Sporophyte & 105.200 & 77.411 & 135.288 & 998 & 0.001 \\
\hline Life stage + habit + Life stage:habit & Low Epiphyte:Sporophyte & -18.553 & -77.984 & 34.518 & 998 & 0.447 \\
\hline Life stage + habit + Life stage:habit & Saxicolous:Sporophyte & -103.496 & -156.991 & -52.861 & 998 & 0.001 \\
\hline Life stage + habit + Life stage:habit & Terrestrial:Sporophyte & -59.072 & -117.259 & -11.485 & 998 & 0.040 \\
\hline \multicolumn{7}{|l|}{ Recovery } \\
\hline Life stage + habit + Life stage:habit & Low Epiphyte & 0.122 & -0.268 & 0.545 & 997 & 0.513 \\
\hline Life stage + habit + Life stage:habit & Saxicolous & 0.119 & -0.309 & 0.600 & 998 & 0.589 \\
\hline Life stage + habit + Life stage:habit & Terrestrial & -0.239 & -0.793 & 0.371 & 1245 & 0.383 \\
\hline Life stage + habit + Life stage:habit & Sporophyte & 0.523 & 0.241 & 0.771 & 997 & 0.001 \\
\hline Life stage + habit + Life stage:habit & Low Epiphyte:Sporophyte & -0.074 & -0.537 & 0.405 & 998 & 0.745 \\
\hline Life stage + habit + Life stage:habit & Saxicolous:Sporophyte & -0.683 & -1.130 & -0.234 & 998 & 0.008 \\
\hline Life stage + habit + Life stage:habit & Terrestrial:Sporophyte & -0.461 & -0.975 & 0.042 & 998 & 0.072 \\
\hline
\end{tabular}

$\mathrm{ETR}_{\max }$, maximum relative electron transport rate; $\mathrm{PPFD}_{95 \%}$, light level at which $95 \%$ of $\mathrm{ETR}_{\text {max }}$ is reached; Recovery, recovery of $\mathrm{F}_{\mathrm{v}} / \mathrm{F}_{\mathrm{m}}(\%)$ following $2 \mathrm{~d}$ desiccation at $-86 \mathrm{MPa}$ Effect of life stage is relative to gametophytes; effect of growth habit is relative to high elevation epiphytes

Significant predictors in bold 
Table 4 Phylogenetic generalized least squares (PLGS) models of desiccation tolerance as a function of vapor pressure deficit (VPD) or the range of gametophytes beyond sporophytes (G beyond S) in filmy ferns from Moorea, French Polynesia

\begin{tabular}{llllll}
\hline Life stage & Predictor & df & $F$ & adj. $R^{2}$ & $P$ \\
\hline S & VPD & 2,12 & 5.421 & 0.254 & 0.038 \\
G & VPD & 2,11 & 3.586 & 0.177 & 0.085 \\
G & G beyond S & 2,12 & 4.127 & 0.194 & 0.065 \\
\hline
\end{tabular}

S, sporophyte; G, gametophyte 


\section{Figure legends}

Fig. 1 Examples of filmy ferns from French Polynesia. (a-d) sporophytes; (e-h) gametophytes. (a) Crepidomanes humile, a low elevation epiphyte. Nitta 3392 (GH). (b) Hymenophyllum multifidum, a high elevation epiphyte growing in association with leafy liverworts and mosses. Nitta 1257 (GH). (c) Polyphlebium endlicherianum, a saxicolous species found at low to middle elevations. Nitta 629 (GH). (d) Callistopteris apiifolia, a terrestrial species with sporophytes occurring only in humid cloud forests. Nitta 3990 (GH). (e) Callistopteris apiifolia (ribbon morphotype). Arrow indicates gemmae (asexual propagules) at tip of lobe. Nitta 2565 (GH). (f) Hymenophyllum polyanthos (ribbon morphotype). Nitta 3862 (GH). (g) Filamentous gametophytes of an unidentified species of Hymenophyllaceae. Nitta 4036 (GH). (h) Callistopteris apiifolia, showing detail of gemmifers (attachment points of gemmae, example indicated by arrow) and branched gemmae. Nitta 3887 (GH). Scalebars: $(\mathbf{a}-\mathbf{c}) 1.0 \mathrm{~cm}$; (d) $5.0 \mathrm{~cm}$; (e) $5.0 \mathrm{~mm}$; (f) $2.0 \mathrm{~mm} ;(\mathbf{g}, \mathbf{h}) 1.0 \mathrm{~mm}$. Photographs by J. H. Nitta.

Fig. 2 Desiccation tolerance of filmy fern sporophytes (a) and gametophytes (b) from Moorea, French Polynesia. Recovery was measured by comparing maximum photochemical yield of photosystem II before desiccation treatment with values at $30 \mathrm{~min}, 24 \mathrm{hr}$, and $48 \mathrm{hr}$ following desiccation at three different intensities for either 2 or 15 days (see Methods). Recovery was not measured for all combinations of species and desiccation treatments; missing points indicate data not collected (not recovery of $0 \%$ ). Error bars indicate standard deviation. $n=8$ samples per species/treatment unless otherwise indicated. Growth habit indicated in parentheses after each species: T, terrestrial; S, saxicolous; LE, low elevation epiphyte; $\mathrm{HE}$, high elevation epiphyte

Fig. 3 Phylogeny of filmy ferns from Moorea, French Polynesia with comparison of physiological parameters (mean $\pm 1 \mathrm{SD}$ ) between sporophytes (dark grey bars) and gametophytes (light grey bars). Phylogeny adapted from Nitta et al. (2016); only species with 
physiological data shown. Bootstrap support $>50 \%$ from $100 \mathrm{ML}$ bootstraps indicated at nodes. Bold letters indicate major clades $(H=$ hymenophylloid clade, $\mathrm{T}=$ trichomanoid clade). Growth habit indicated by colored symbols (blue = low elevation epiphyte, green $=$ high elevation epiphyte, yellow = saxicolous, red $=$ terrestrial). Crepidomanes bipunctatum and $C$. humile were observed growing as both epiphytes and saxicoles, but are shown as epiphytes to distinguish them from exclusively saxicolous species. Asterisk indicates significant difference in means $(P<0.05)$ between life stages for a particular species (t-test); ns indicates no significant difference; lack of ns or asterisk means not enough observations available for that species for $t$-test. Left bar plot shows recovery (\%) of chlorophyll fluorescence $\left(\mathrm{F}_{\mathrm{v}} / \mathrm{F}_{\mathrm{m}}\right)$ following 2 day desiccation at -86 MPa (Abrodictyum dentatum was desiccated at -38 MPa instead of -86 MPa). Middle bar plot shows maximum relative electron transport rate of photosystem II $\left(E T R_{\max }\right)\left(\mu \mathrm{mol} \mathrm{e}^{-\cdot} \mathrm{m}^{-2} \cdot \mathrm{s}^{-1}\right)$. Right bar plot shows photosynthetic photon flux density at 95\% saturation of RETR (PPFD ${ }_{95 \%}$ ) $\left(\mu \mathrm{mol}\right.$ quanta $\left.\cdot \mathrm{m}^{-2} \cdot \mathrm{s}^{-1}\right)$. Absence of a bar indicates measurements not available for gametophytes or sporophytes of that species.

Fig. 4 Recovery of $F_{v} / F_{m}(\%)$ following $2 \mathrm{~d}$ desiccation at $-86 \mathrm{MPa}$ plotted against environmental vapor pressure deficit (VPD; kPa) (a, b) or range of gametophytes beyond sporophytes $(\mathrm{m})(\mathbf{c})$ for gametophytes $(\mathbf{a}, \mathbf{c})$ or sporophytes $(\mathbf{b})$. Species means \pm 1 SD are shown. Growth habit indicated by colored symbols (blue = low elevation epiphyte, green = high elevation epiphyte, yellow = saxicolous, red $=$ terrestrial). Crepidomanes bipunctatum and $C$. humile were observed growing as both epiphytes and saxicoles, but were treated as epiphytes to distinguish them from exclusively saxicolous species. Abrodictyum dentatum sporophytes were desiccated at -38 MPa instead of -86 MPa. Range of gametophytes beyond sporophytes calculated as the total elevation that gametophytes exceeded sporophytes at either end of the elevational gradient. Relationships between recovery and VPD or range of gametophytes beyond sporophytes were analyzed with phylogenetic generalized least squares (PGLS); significant relationships $(P<0.05)$ shown with grey line. 


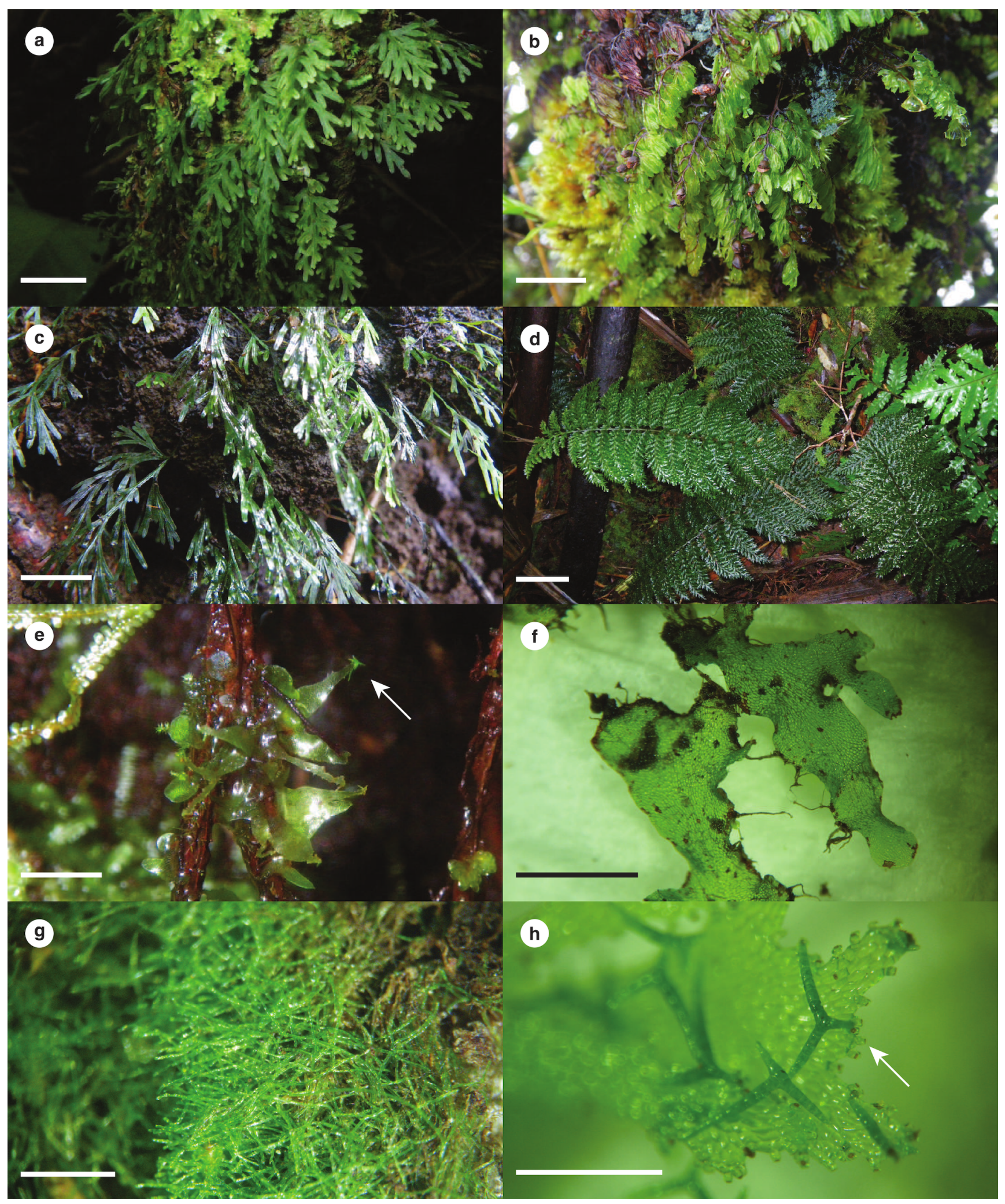

Fig. 1 
a
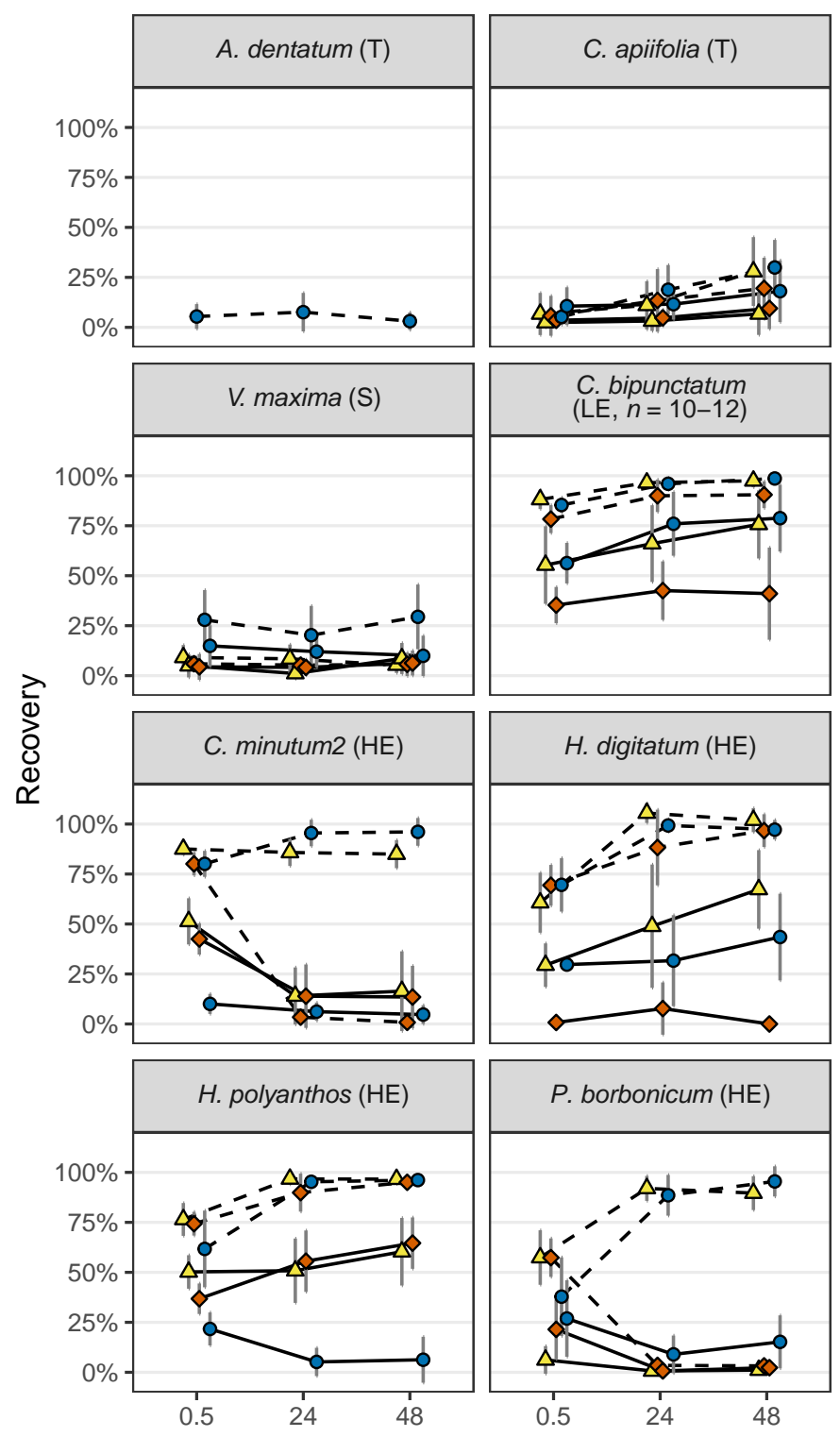
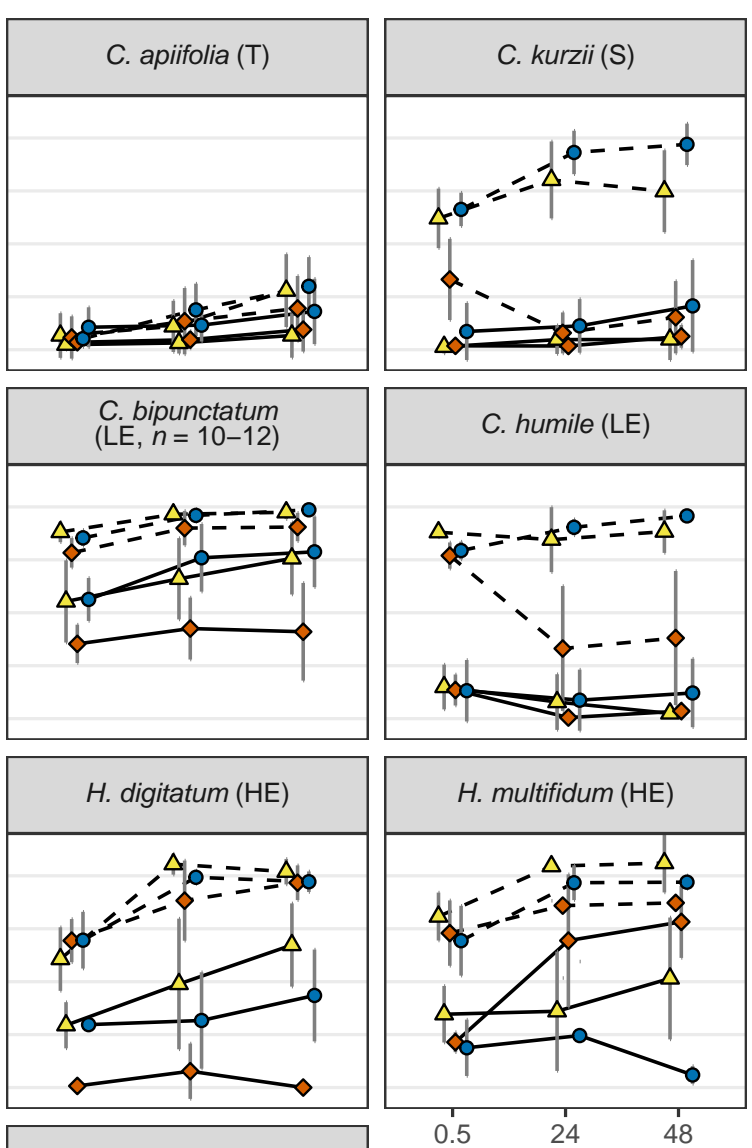

P. borbonicum (HE)

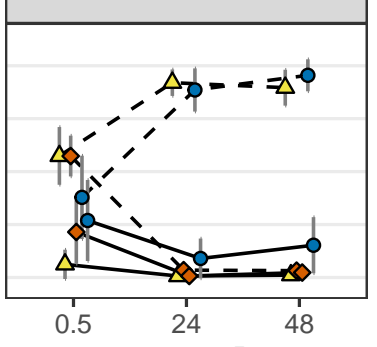

Recovery Time (hr)

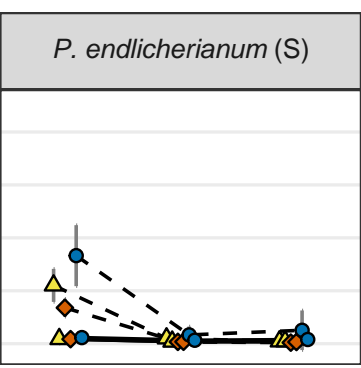

D. tahitense (LE)

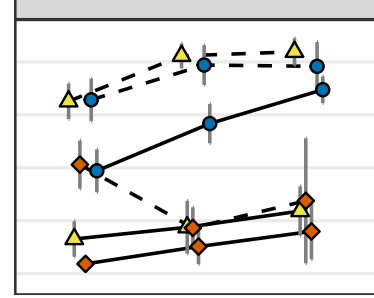

H. pallidum (HE)

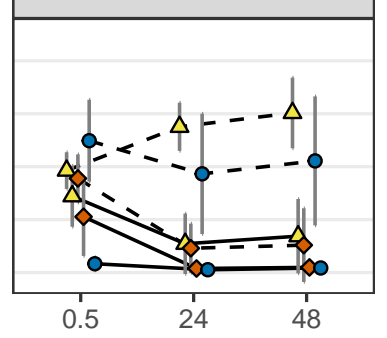

Desiccation Time - 15 days - - 2 days

Desiccation Intensity $\quad \circ \quad-38 \mathrm{MPa} \quad \Delta \quad-86 \mathrm{MPa} \quad \diamond \quad-282 \mathrm{Mpa}$

Fig. 2 
bioRxiv preprint doi: https://doi.org/10.1101/2021.03.12.435213; this version posted May 6, 2021. The copyright holder for this preprint (which was not certified by peer review) is the author/funder, who has granted bioRxiv a license to display the preprint in perpetuity. It is made available under aCC-BY 4.0 International license.

b
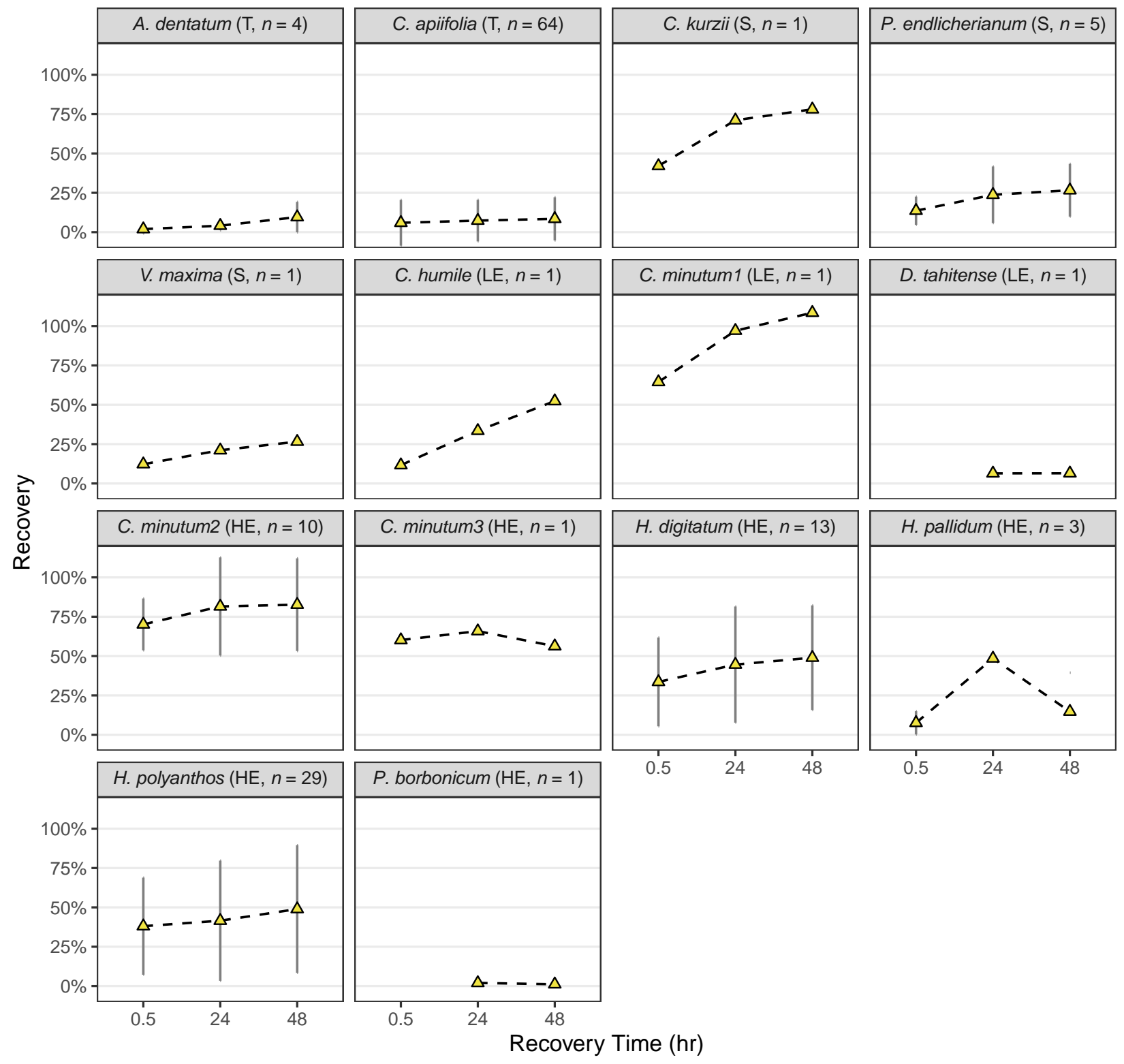

Desiccation Time --2 days
Desiccation Intensity $\Delta \quad-86 \mathrm{MPa}$

Fig. 2 (continued) 
bioRxiv preprint doi: https://doi.org/10.1101/2021.03.12.435213; this version posted May 6, 2021. The copyright holder for this preprint (which was not certified by peer review) is the author/funder, who has granted bioRxiv a license to display the preprint in perpetuity. It is made available under aCC-BY 4.0 International license.

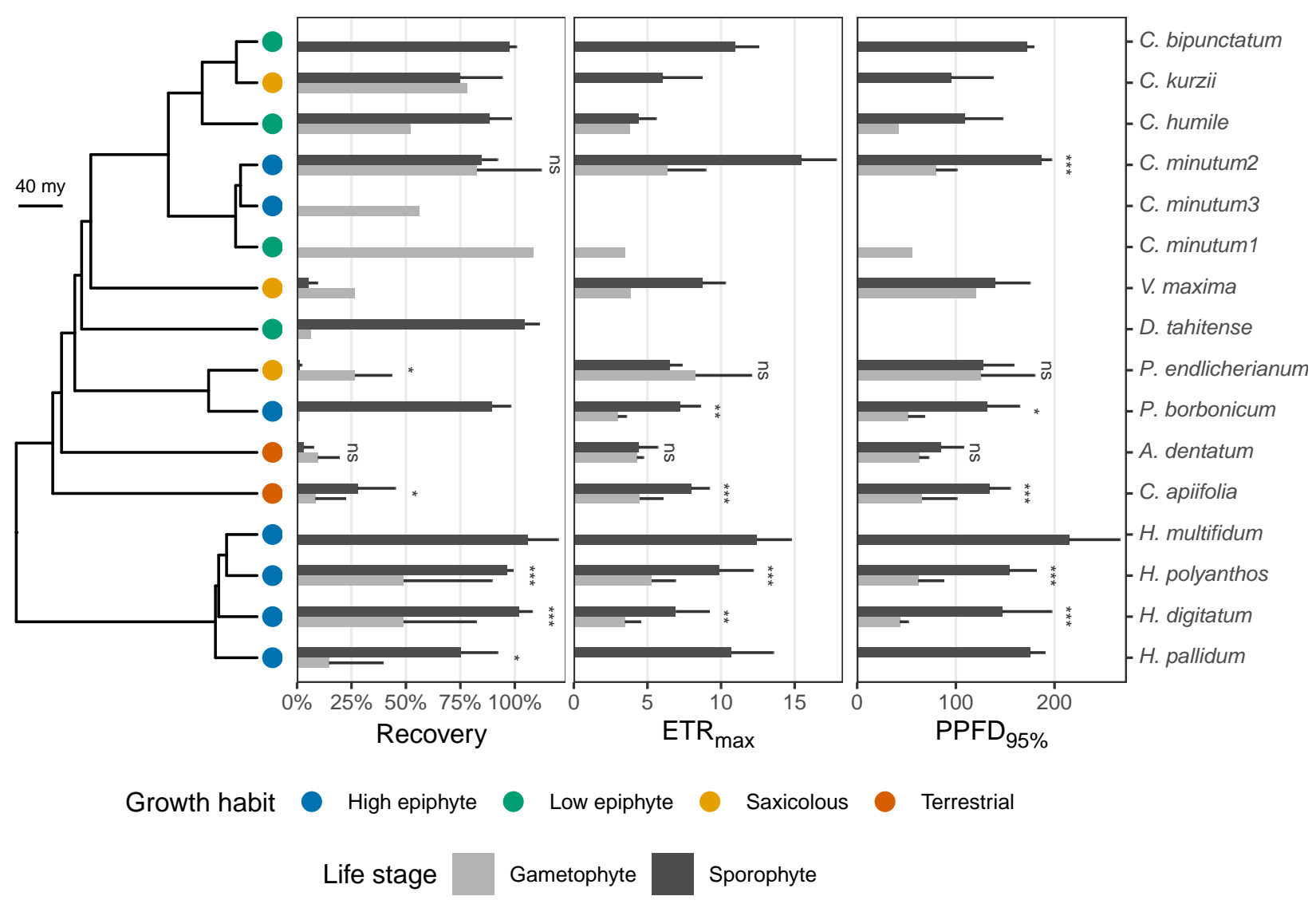

Fig. 3 
bioRxiv preprint doi: https://doi.org/10.1101/2021.03.12.435213; this version posted May 6, 2021. The copyright holder for this preprint (which was not certified by peer review) is the author/funder, who has granted bioRxiv a license to display the preprint in perpetuity. It is made available under aCC-BY 4.0 International license.

a

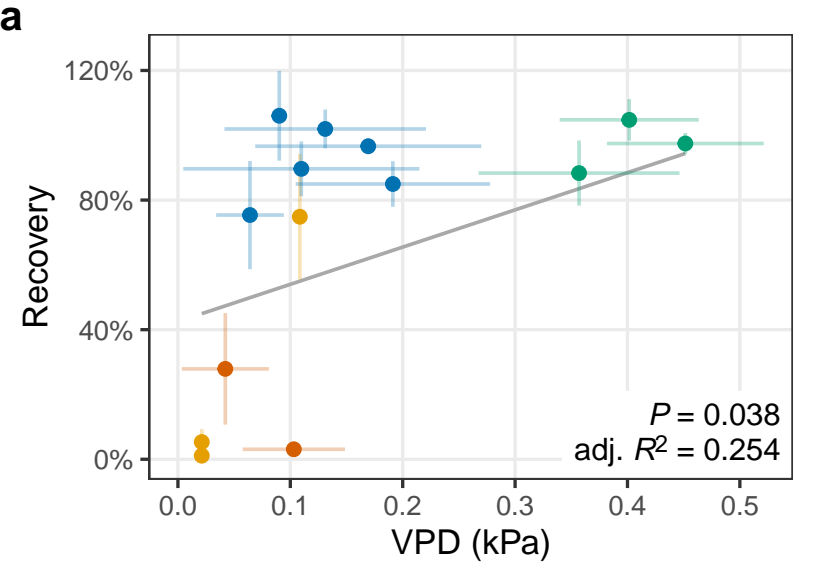

C

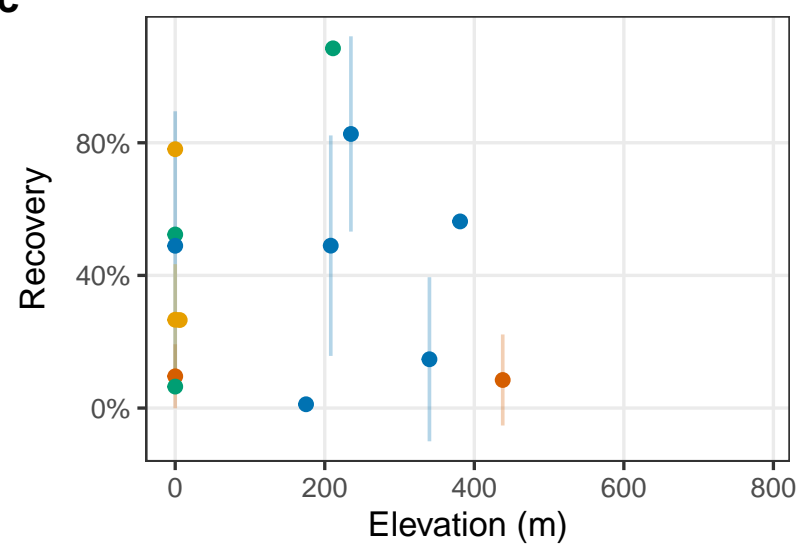

b

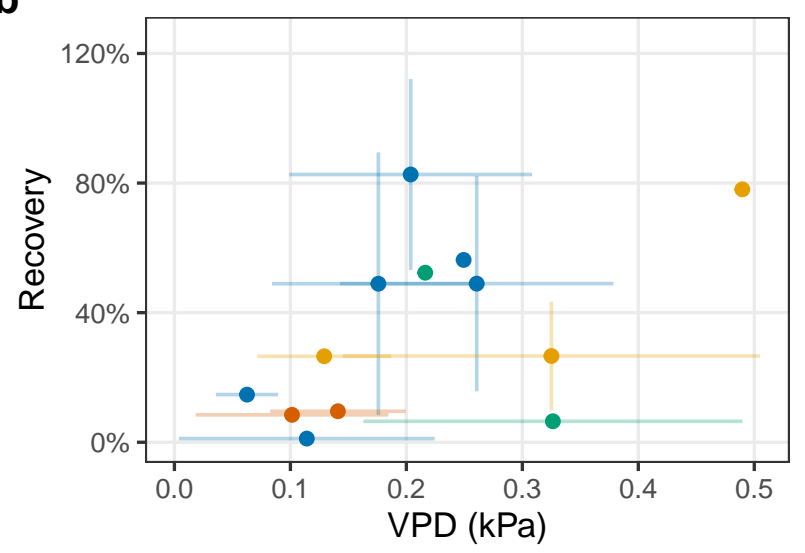

Fig. 4

Growth habit

High epiphyte

- Low epiphyte

- Saxicolous

- Terrestrial 